Cochrane Database of Systematic Reviews

\title{
Interventions for treating leg ulcers in people with sickle cell disease (Review)
}

Martí-Carvajal AJ, Knight-Madden JM, Martinez-Zapata MJ

Martí-Carvajal AJ, Knight-Madden JM, Martinez-Zapata MJ.

Interventions for treating leg ulcers in people with sickle cell disease.

Cochrane Database of Systematic Reviews 2014, Issue 12. Art. No.: CD008394.

DOI: 10.1002/14651858.CD008394.pub3.

www.cochranelibrary.com 
TABLE OF CONTENTS

HEADER 1

ABSTRACT

PLAIN LANGUAGE SUMMARY

SUMMARY OF FINDINGS

BACKGROUND

Figure 1.

OBJECTIVES

METHODS

RESULTS

Figure 2.

Figure 3.

Figure 4.

DISCUSSION

AUTHORS' CONCLUSIONS

ACKNOWLEDGEMENTS

REFERENCES

CHARACTERISTICS OF STUDIES

DATA AND ANALYSES

Analysis 1.1. Comparison $1 \mathrm{~L}$-carnitine versus placebo, Outcome 1 Change in ulcer size (surface area or volume).

Analysis 2.1. Comparison 2 RGD peptide matrix versus placebo, Outcome 1 Incidence of complete closure.

Analysis 2.2. Comparison 2 RGD peptide matrix versus placebo, Outcome 2 Change in size of ulcers healed.

Analysis 2.3. Comparison 2 RGD peptide matrix versus placebo, Outcome 3 Adverse events.

WHAT'S NEW

HISTORY

CONTRIBUTIONS OF AUTHORS

DECLARATIONS OF INTEREST 
[Intervention Review]

\section{Interventions for treating leg ulcers in people with sickle cell disease}

Arturo J Martí-Carvajal'1, Jennifer M Knight-Madden², Maria José Martinez-Zapata3

1/beroamerican Cochrane Network, Valencia, Venezuela. 2Sickle Cell Unit, Tropical Medicine Research Institute, Kingston 7, Jamaica. 3Iberoamerican Cochrane Centre, Biomedical Research Institute Sant Pau (IIB Sant Pau), CIBER Epidemiología y Salud Pública (CIBERESP), Barcelona, Spain

Contact address: Arturo J Martí-Carvajal, Iberoamerican Cochrane Network, Valencia, Venezuela. arturo.marti.carvajal@gmail.com.

Editorial group: Cochrane Cystic Fibrosis and Genetic Disorders Group.

Publication status and date: New search for studies and content updated (no change to conclusions), published in Issue 12, 2014.

Citation: Martí-Carvajal AJ, Knight-Madden JM, Martinez-Zapata MJ. Interventions for treating leg ulcers in people with sickle cell disease. Cochrane Database of Systematic Reviews 2014, Issue 12. Art. No.: CD008394. DOI: 10.1002/14651858.CD008394.pub3.

Copyright @ 2014 The Cochrane Collaboration. Published by John Wiley \& Sons, Ltd.

\section{A B S T R A C T}

\section{Background}

The frequency of skin ulceration makes it an important contributor to the morbidity burden in people with sickle cell disease. Many treatment options are available to the healthcare professional, although it is uncertain which treatments have been assessed for effectiveness in people with sickle cell disease.

\section{Objectives}

To assess the clinical effectiveness and safety of interventions for treating leg ulcers in people with sickle cell disease.

\section{Search methods}

We searched the Cochrane Cystic Fibrosis and Genetic Disorders Group's Haemoglobinopathies Trials Register.

We searched LILACS (1982 to August 2012), the African Index Medicus (up to August 2012), ISI Web of Knowledge (1985 to August 2012), and the Clinical Trials Search Portal of the World Health Organization (August 2012). We checked the reference lists of all the trials identified. We also contacted those groups or individuals who may have completed relevant randomised trials in this area.

Date of the last search of the Cochrane Cystic Fibrosis and Genetic Disorders Group's Haemoglobinopathies Trials Register: 21 July 2014 ; date of the last search of the Cochrane Wounds Group Trials Register: 18 September 2014.

\section{Selection criteria}

Randomised controlled trials of interventions for treating leg ulcers in people with sickle cell disease compared to placebo or an alternative treatment.

\section{Data collection and analysis}

Two authors independently selected studies for inclusion. All three authors independently assessed the risk of bias of the included studies and extracted data.

\section{Main results}

Six studies met the inclusion criteria (198 participants with 250 ulcers). Each trial investigated a different intervention and within this review we have grouped these as systemic pharmaceutical interventions (L-cartinine, arginine butyrate, isoxsuprine) and topical pharmaceutical interventions (Solcoseryl ${ }^{\circledR}$ cream, RGD peptide dressing, topical antibiotics). Three interventions reported on the change in ulcer size (arginine butyrate, RGD peptide, L-cartinine). Of these, RGD peptide matrix significantly reduced ulcer size compared with a control group, mean reduction $6.60 \mathrm{~cm}^{2}$ (95\% Cl 5.51 to 7.69 ; very low quality of evidence). Three trials reported on the incidence of complete closure 
(isoxsuprine, arginine butyrate, RGD peptide matrix; ranging between low and very low quality of evidence). None reported a significant effect. No trial reported on: the time to complete ulcer healing; ulcer-free survival following treatment for sickle cell leg ulcers; quality of life measures; or incidence of amputation. There was no reported information on the safety of these interventions.

\section{Authors' conclusions}

There is evidence that a topical intervention (RGD peptide matrix) reduced ulcer size in treated participants compared to controls. This evidence of efficacy is limited by the generally high risk of bias associated with these reports.

We planned to analyse results according to general groups: pharmaceutical interventions (systemic and topical); and non-pharmaceutical interventions (surgical and non-surgical). However, we were unable to pool findings due to the heterogeneity in outcome definitions, and inconsistency between the unit of randomisation and the unit of analysis. This heterogeneity, along with a paucity of identified trials, prevented us performing any meta-analyses.

This Cochrane review provides some evidence for the effectiveness of one topical intervention - RGD peptide matrix. However, this intervention was assessed as having a high risk of bias due to inadequacies in the single trial report. Other included studies were also assessed as having a high risk of bias. We recommend that readers interpret the trial results with caution. The safety profile of the all interventions was inconclusive.

\section{PLAIN LANGUAGE SUMMARY}

\section{Treatments for leg ulcers in people with sickle cell disease}

Leg ulcers are a chronic complication for people living with sickle cell disease. Ulcers tend to be difficult to treat successfully, healing slowly over months or years. They can severely disrupt quality of life, increase disability, require extended absence from the workplace, and place a high burden of care on healthcare systems. We looked at whether treatments for leg ulcers in people with sickle cell disease were effective and safe.

In this Cochrane review we found six randomised controlled trials including 198 participants with 250 ulcers. Four of the randomised controlled trials were conducted in Jamaica and two in the USA. These trials included medications or dressings applied directly to the ulcer (topical medications) and medications given orally or intravenously (systemic medications). Given the very different modes of action of these two groups, we treated them separately throughout the review. The topical agents included Solcoseryl ${ }^{\circledR}$ cream, RGD peptide matrix dressing and topical antibiotics. Socoseryl aims to improve the use of oxygen by the skin tissue and so promote wound healing. Topical antibiotics are also used to prevent infection. The RGD peptide matrix is a gel that promotes cell growth. The systemic interventions included arginine butyrate, L-cartinine, and isoxsuprine. Aginine butyrate, given intravenously, is thought to accelerate wound healing, Lcarnitine, given orally, is thought to improve tissue hypoxia, and isoxsuprine, given orally as isoxsuprine hydrochloride, is thought to widen blood vessels, so increasing blood flow to an affected wound.

One medication, a topical intervention (RGD peptide matrix) reduced ulcer size in treated participants compared to controls. However, this effect should be interpreted with caution given the high risk of bias due to the inadequacies associated with this trial report.

The evidence for the use of interventions to treat people with sickle cell disease and chronic leg ulceration is not strong. All randomised clinical trials that we included in this review were associated with a high risk of bias. This systematic review has shown the need for welldesigned, high-quality randomised trials to assess the benefits and harms of interventions to improve the healing of leg ulcers in people with sickle cell disease. 
SUMMARY OF FINDINGS

Summary of findings for the main comparison. Isoxuprine compared to placebo for leg ulcer in people with sickle cell disease

Isoxuprine compared to placebo for leg ulcer in people with sickle cell disease

Patient or population: patients with leg ulcer in people with sickle cell disease

Settings:

Intervention: Isoxuprine

Comparison: placebo

\begin{tabular}{|c|c|c|c|c|c|c|}
\hline \multirow[t]{3}{*}{ Outcomes } & \multicolumn{2}{|c|}{$\begin{array}{l}\text { Illustrative comparative risks* (95\% } \\
\mathrm{Cl} \text { ) }\end{array}$} & \multirow{3}{*}{$\begin{array}{l}\text { Relative ef- } \\
\text { fect } \\
(95 \% \mathrm{Cl})\end{array}$} & \multirow[t]{3}{*}{$\begin{array}{l}\text { No of Participants } \\
\text { (studies) }\end{array}$} & \multirow{3}{*}{$\begin{array}{l}\text { Quality of the } \\
\text { evidence } \\
\text { (GRADE) }\end{array}$} & \multirow[t]{3}{*}{ Comments } \\
\hline & Assumed risk & $\begin{array}{l}\text { Corresponding } \\
\text { risk }\end{array}$ & & & & \\
\hline & placebo & Isoxuprine & & & & \\
\hline $\begin{array}{l}\text { Incidence of com- } \\
\text { plete closure } \\
\text { Follow-up: } 6\end{array}$ & See comment & See comment & Not estimable & $\begin{array}{l}54 \text { ulcers } \\
\text { (1 study; Serjeant } \\
1977)\end{array}$ & $\begin{array}{l}\oplus \ominus \ominus \ominus \\
\text { very low } 1,2,3\end{array}$ & $\begin{array}{l}\text { This trial shows inconsistency between } \\
\text { units of randomisation ( } 30 \text { participants) and } \\
\text { unit of analysis ( } 54 \text { ulcers). }\end{array}$ \\
\hline
\end{tabular}

*The basis for the assumed risk (e.g. the median control group risk across studies) is provided in footnotes. The corresponding risk (and its $95 \%$ confidence interval) is based on the assumed risk in the comparison group and the relative effect of the intervention (and its $95 \% \mathrm{Cl}$ ).

GRADE Working Group grades of evidence

High quality: Further research is very unlikely to change our confidence in the estimate of effect.

Moderate quality: Further research is likely to have an important impact on our confidence in the estimate of effect and may change the estimate.

Low quality: Further research is very likely to have an important impact on our confidence in the estimate of effect and is likely to change the estimate.

Very low quality: We are very uncertain about the estimate.

1 Sequence generation, allocation concealment, blinding: unclear. Incomplete outcome data and selective report.

2 Underpowered for this outcome.

3 Few ulcers $(\mathrm{N}=54)$ and healed ulcers $(\mathrm{N}=11)$

$\mathrm{Cl}$ : confidence interval

Summary of findings 2. Arginine butyrate plus standard local care compared to standard local care for sickle cell in people with sickle cell disease

arginine butyrate plus standard local care compared to standard local care for sickle cell in people with sickle cell disease 
Patient or population: sickle cell in people with sickle cell disease

Settings:

Intervention: arginine butyrate plus standard local care

Comparison: standard local care

\begin{tabular}{|c|c|c|c|c|c|c|}
\hline \multirow[t]{3}{*}{ Outcomes } & \multicolumn{2}{|c|}{$\begin{array}{l}\text { Illustrative comparative risks* }(95 \% \\
\mathrm{CI})\end{array}$} & \multirow{3}{*}{$\begin{array}{l}\text { Relative ef- } \\
\text { fect } \\
(95 \% \mathrm{Cl})\end{array}$} & \multirow[t]{3}{*}{$\begin{array}{l}\text { No of Participants } \\
\text { (studies) }\end{array}$} & \multirow{3}{*}{$\begin{array}{l}\text { Quality of the } \\
\text { evidence } \\
\text { (GRADE) }\end{array}$} & \multirow[t]{3}{*}{ Comments } \\
\hline & Assumed risk & Corresponding risk & & & & \\
\hline & $\begin{array}{l}\text { standard lo- } \\
\text { cal care }\end{array}$ & $\begin{array}{l}\text { arginine butyrate } \\
\text { plus standard local } \\
\text { care }\end{array}$ & & & & \\
\hline $\begin{array}{l}\text { Complete heal- } \\
\text { ing } \\
\text { Follow-up: } 12 \\
\text { weeks }\end{array}$ & See comment & See comment & Not estimable & $\begin{array}{l}23 \text { participants } \\
62 \text { ulcers } \\
\text { (1 study; McMahon } \\
2010 \text { ) }\end{array}$ & $\begin{array}{l}\oplus \ominus \odot \odot \\
\text { very low } 1,2,3\end{array}$ & $\begin{array}{l}\text { This trial shows inconsistency between units } \\
\text { of randomisation ( } 23 \text { participants) and unit of } \\
\text { analysis ( } 62 \text { ulcers). }\end{array}$ \\
\hline $\begin{array}{l}\text { Change in ulcer } \\
\text { size } \\
\text { Follow-up: } 12 \\
\text { weeks }\end{array}$ & See comment & See comment & Not estimable & $\begin{array}{l}\text { (1 study; McMahon } \\
\text { 2010) }\end{array}$ & $\begin{array}{l}\oplus \odot \odot \odot \\
\text { very low 1,2,3 }\end{array}$ & $\begin{array}{l}\text { This trial shows inconsistency between units } \\
\text { of randomisation ( } 23 \text { participants) and unit of } \\
\text { analysis ( } 62 \text { ulcers). }\end{array}$ \\
\hline
\end{tabular}

*The basis for the assumed risk (e.g. the median control group risk across studies) is provided in footnotes. The corresponding risk (and its $95 \% \mathrm{Cl}$ ) is based on the assumed risk in the comparison group and the relative effect of the intervention (and its $95 \% \mathrm{Cl}$ ).

GRADE Working Group grades of evidence

High quality: Further research is very unlikely to change our confidence in the estimate of effect.

Moderate quality: Further research is likely to have an important impact on our confidence in the estimate of effect and may change the estimate.

Low quality: Further research is very likely to have an important impact on our confidence in the estimate of effect and is likely to change the estimate.

Very low quality: We are very uncertain about the estimate.

1 Unclear allocation concealment

2 Underpowered for this outcome.

3 Few participants ( 23 participants; 62 ulcers) and events ( $N=13$ complete closure)

$\mathrm{Cl}$ : confidence interval

Summary of findings 3. L-carnitine compared to placebo for leg ulcer in people with sickle cell disease

L-carnitine compared to placebo for leg ulcer in people with sickle cell disease 


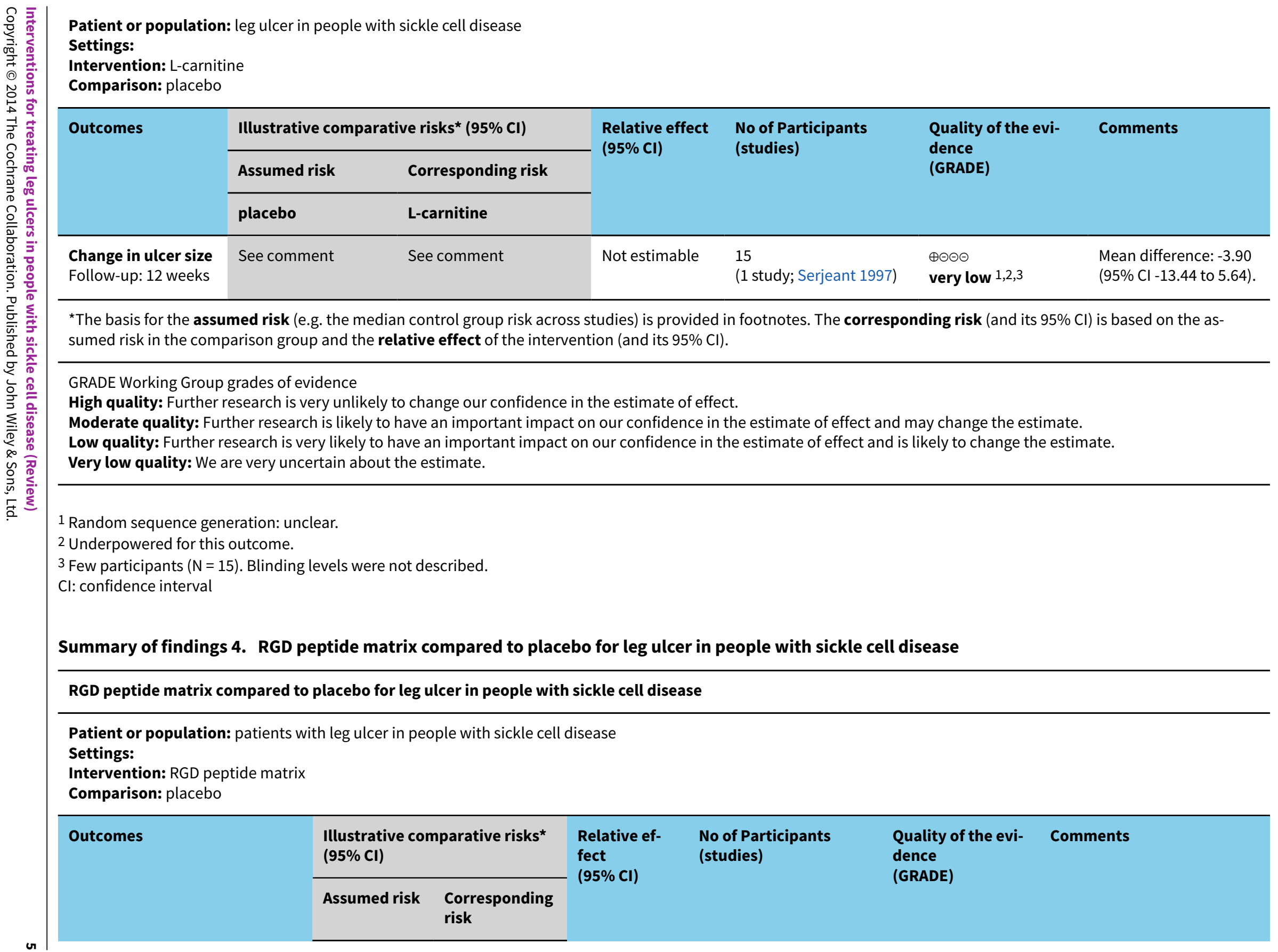




\begin{tabular}{|c|c|c|c|c|c|c|}
\hline & placebo & $\begin{array}{l}\text { RGD peptide } \\
\text { matrix }\end{array}$ & & & & \\
\hline $\begin{array}{l}\text { Complete closure } \\
\text { Follow-up: } 10 \text { weeks }\end{array}$ & See comment & See comment & Not estimable & $\begin{array}{l}55 \\
\text { (1 study; Wethers 1994) }\end{array}$ & $\begin{array}{l}\oplus \ominus \ominus \ominus \\
\text { very low } 1,2,3\end{array}$ & $\begin{array}{l}\text { Risk ratio: } 0.40 \text { ( } 95 \% \mathrm{Cl} 0.15 \text { to } \\
\text { 1.04). }\end{array}$ \\
\hline $\begin{array}{l}\text { Change in size ulcers healed } \\
\mathrm{cm} 2 \\
\text { Follow-up: } 10 \text { weeks }\end{array}$ & See comment & See comment & Not estimable & $\begin{array}{l}55 \\
\text { (1 study; Wethers 1994) }\end{array}$ & $\begin{array}{l}\oplus \odot \Theta \odot \\
\text { very low 1,2,3 }\end{array}$ & $\begin{array}{l}\text { Mean difference: } 6.60(95 \% \mathrm{Cl} \\
5.51 \text { to } 7.69) \text {. }\end{array}$ \\
\hline $\begin{array}{l}\text { Total adverse events } \\
\text { Follow-up: } 10 \text { weeks }\end{array}$ & See comment & See comment & Not estimable & $\begin{array}{l}55 \\
\text { (1 study; Wethers 1994) }\end{array}$ & $\begin{array}{l}\oplus \odot \Theta \odot \\
\text { very low 1,2,3 }\end{array}$ & $\begin{array}{l}\text { Risk ratio: } 0.76 \text { (95 } \mathrm{Cl} 0.50 \text { to } \\
1.17) \text {. }\end{array}$ \\
\hline $\begin{array}{l}\text { Related study treatment ad- } \\
\text { verse events } \\
\text { Follow-up: } 10 \text { weeks }\end{array}$ & See comment & See comment & Not estimable & $\begin{array}{l}33 \\
\text { (1 study; Wethers 1994) }\end{array}$ & $\begin{array}{l}\oplus \odot \Theta \odot \\
\text { very low 1,2,3 }\end{array}$ & $\begin{array}{l}\text { Risk Ratio: } 1.41 \text { ( } 95 \% \text { Cl } 0.27 \\
\text { to } 7.38) \text {. }\end{array}$ \\
\hline \multicolumn{7}{|c|}{$\begin{array}{l}\text { *The basis for the assumed risk (e.g. the median control group risk across studies) is provided in footnotes. The corresponding risk (and its } 95 \% \mathrm{Cl} \text { ) is based on the as- } \\
\text { sumed risk in the comparison group and the relative effect of the intervention (and its } 95 \% \mathrm{Cl} \text { ). }\end{array}$} \\
\hline \multicolumn{7}{|c|}{$\begin{array}{l}\text { GRADE Working Group grades of evidence } \\
\text { High quality: Further research is very unlikely to change our confidence in the estimate of effect. } \\
\text { Moderate quality: Further research is likely to have an important impact on our confidence in the estimate of effect and may change the estimate. } \\
\text { Low quality: Further research is very likely to have an important impact on our confidence in the estimate of effect and is likely to change the estimate. } \\
\text { Very low quality: We are very uncertain about the estimate. }\end{array}$} \\
\hline
\end{tabular}

1 Sequence generation and allocation concealment: unclear

2 Underpowered to address this outcome

3 Few participants $(N=55)$ and events $(N=14)$

$\mathrm{Cl}$ : confidence interval 


\section{B A C K G R O U N D}

See Appendix 1 for a glossary of medical terms.

\section{Description of the condition}

Sickle cell disease (SCD) is an inherited disease and the most common haemoglobinopathy worldwide (Ballas 2010; Orkin 2010; Rees 2010). Recently, the clinical history and others aspects of SCD have been reviewed (Mousa 2010; Prabhakar 2010; Serjeant 2010). It is common among people with sub-Saharan African, Indian, Middle Eastern or Mediterranean ancestry (Creary 2007; Modell 2008). Sickle cell disease is a major public health problem (Modell 2008) with an estimated $70 \%$ of sufferers living in Africa (Makani 2007). Screening programmes for detecting SCD are ongoing worldwide (e.g. Bardakdjian-Michau 2009; Daudt 2007; Henthorn 2004; Mañú 2009; Gulbis 2006; Tshilolo 2008). The term SCD includes sickle cell anaemia (Hb SS), haemoglobin S combined with haemoglobin $\mathrm{C}$ ( $\mathrm{Hb} \mathrm{SC}$ ), haemoglobin $\mathrm{S}$ associated with $\beta$ thalassemia ( $S ß O$ Thal and $\mathrm{S} ß+$ Thal) and other less prevalent double heterozygous conditions which cause clinical disease (Steinberg 2009; Weatherall 2006). Haemoglobin S combined with normal haemoglobin (A) is known as the sickle cell trait (AS), which is generally asymptomatic and is not part of this review.
One chronic complication of SCD is the sickle cell leg ulcer (SCLU) (Figure 1) (Knox-Macaulay 1983; Minniti 2010; Ramalho 1985). The frequency of skin ulceration makes it an important contributor to the morbidity burden faced by people with SCD, and resistance to therapy makes chronicity an important feature of the condition. Although there is no universally accepted leg ulcer duration that defines the condition as chronic, a research definition from Jamaica has defined a chronic leg ulcer as "an active ulcer recorded at least twice over a minimum period of three months" (Alexander 2004; Serjeant 2005). A SCLU can be a physically disabling complication, with potentially negative psychological and social consequences. It has been considered a marker of disease severity by some authors (Alleyne 1977; Cumming 2008; Eckman 1996; Halabi -Tawil 2008). The rationale behind this severity statement is based on an increasing risk of priapism and pulmonary hypertension in those individuals with SCLU (Halabi-Tawil 2008; Serarslan 2009). People with homozygous SCD and a leg ulcer have a higher prevalence of pulmonary hypertension compared to people with homozygous SCD without a leg ulcer (Serarslan 2009). These vasculopathies have a common denominator: a chronic intravascular hyper-haemolysis which generate a lower level of nitric oxide (Akinsheye 2010; Taylor 2008). Others have used multivariate statistical modelling to explore possible clinical phenotypes in people with homozygous SCD and have suggested a 'leg ulcer phenotype' (Alexander 2004).

\section{Figure 1.}

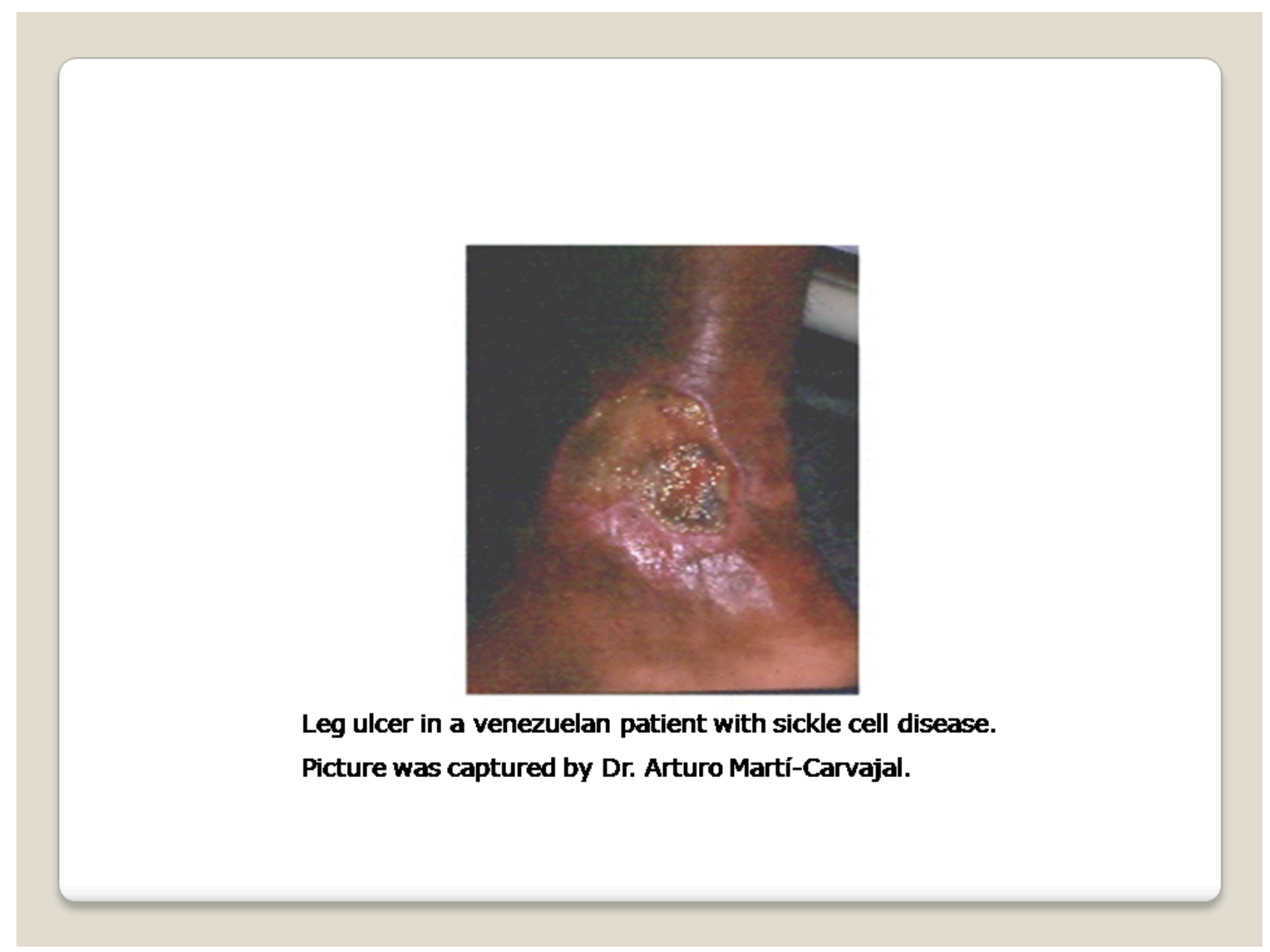


Individuals with $\mathrm{Hb}$ SS are more likely to experience a leg ulcer than those with other genotypes (Ankra-Badu 1992; Koshy 1989). Geographically, the reported prevalence of this complication varies. In Nigeria, the prevalence of SCLU ranges between $7.5 \%$ for people with HbSS and 1.5\% for people with HbSC (Akinyanju 1979; Durosinmi 1991). According to the 'Cooperative Study of Sickle Cell Disease' in the USA, leg ulcers affected $2.5 \%$ of people with SCD, with a higher rate of between $4 \%$ and $5 \%$ among those with HbSS (Koshy 1989). In Jamaica, a lifetime prevalence of any leg ulceration was reported to be between $70 \%$ and $80 \%$ (Serjeant 2005). More recently a prevalence of ulcers lasting six months or more was reported as $29.5 \%$ and the cumulative incidence as $16.7 \%$ (Cumming 2008). These prevalence rate variations are partly due to differing patient age distributions and analysis methodologies. It is generally agreed that leg ulcers are most commonly reported in adolescence and early adulthood in individuals with SCD (Serjeant 2005).

The SCLUs generally occur in areas with less subcutaneous fat, with thin skin, and with decreased blood flow (Trent 2004). The commonest sites are the medial and lateral malleoli (ankles), often becoming circumferential if not controlled early; the medial malleolus is more commonly involved than the lateral malleolus (Serjeant 2005; Trent 2004) (Figure 1). Less common sites are the anterior tibial area, dorsum of the foot, and achilles tendon area (Trent 2004).

The pathogenesis of the SCLU is complex (Aslan 2007; Hagar 2008; Kato 2007; Kato 2009; Mack 2006; Morris 2008; Paladino 2007; Serjeant 2005; Trent 2004; Wood 2008). One or more of the following mechanisms could play a role in the development of leg ulcers in people with SCD:

1. decreased nitric oxide: the haemolysis (breakdown) of the sickle red blood cells releases haemoglobin into the blood stream which consumes nitric oxide (a powerful vasodilator agent) to the blood, perhaps leading to impaired endothelial function (Mack 2006);

2. infectious process: the role of bacterial infection or colonization, or both, is illustrated by the growth of organisms such as Staphylococcus aureus, Pseudomonas aeruginosa and group A streptococci from ulcer swabs, signs of local inflammation and regional lymphadenopathy (MacFarlane 1986; Mohan 2000; Sehgal 1992);

3. venous incompetence: low oxygen tension in the venous system, inevitable turbulence around venous valves and high white blood cell and platelet counts promote endothelial adhesion and chronic ischemia (Chalchal 2001; Clare 2002; Cumming 2008; Mohan 2000; Serjeant 2005);

4. blood hypercoagulability: an acquired antithrombin III deficiency that has been described in individuals with SCLUs, along with evidence of fibrinolysis (D-dimer fragment, and fibrinogen or fibrin degradation products) (Cacciola 1990a);

5. defective immunity: the complement system contributes to the immune system's defence against infection, and an inability to fix this system has been proposed as a risk factor for developing this chronic complication (Morgan 1981);

6. genetic risk factors: there is a relationship between genes of the TGF-beta/BMP superfamily and endothelial function and nitric oxide biology which may explain the genesis of the SCLU (Nolan 2006; Ofosu 1987; Steinberg 2009).

7. postural vasoconstriction: by using the laser Doppler flowmeter, it had been demonstrated that individuals with SCLU have a low red cell flux at the ulcer or scar site (Mohan 1997).

In brief, the increased susceptibility to leg ulcers in people with SCD is due to a chronic ischemia and defective immunity. Chronic ischemia may be explained by a blood hypercoagulability, venous incompetence, or postural vasoconstriction, with these mechanisms conditioned by a low nitric oxide that may itself be genetically influenced.

\section{Description of the intervention}

There are a wide range of possible treatments for leg ulcers in people with SCD, and many of these treatments have been considered as interventions among people with leg or foot ulcers resulting from other pathologies, e.g. a silver-based wound dressing and topical agents for treating diabetic foot ulcers (Bergin 2006; O'Meara 2010), the debridement of diabetic foot ulcers (Edwards 2002), oral zinc for arterial and venous leg ulcers (Wilkinson 1998) and compression for venous leg ulcers (O'Meara 2009). Conventional care would generally include occlusive dressing (Palfreyman 2006; Vermeulen 2004; Wasiak 2008) and debridement and cleansing (Moore 2005; Nelson 2000; Smith 2011). It is unknown if ulcers in people with SCD might experience differential benefits of these common treatments compared to ulcers from other pathologies.

Many possible treatments exist as adjuncts to conventional treatment and we have classified these into two major treatment groups: pharmaceutical interventions; and non-pharmaceutical interventions.

\section{Pharmaceutical interventions}

\section{a. Systemic pharmaceutical interventions:}

i. vascular drugs (such as pentoxifylline (blood viscosityreducing agent) (Frost 1990), isoxsuprine hydrochloride ( $\beta$-adrenergic receptor stimulant) (Serjeant 1977), xanthinol nicotinate (vasodilator) (Afifi 1979));

ii. antioxidant agents (such as L-carnitine) (Harrel 1990; Serjeant 1997);

iii. recombinant agents and related (such as recombinant human erythropoietin (erythropoiesis-stimulating agent which increases the haemoglobin levels) (al-Momen 1991), antithrombin III concentrate (potent coagulation inhibitor) (Cacciola 1989));

iv. growth factors: such as Bosentan (a receptor endothelin receptor blocker) (Lionnet 2008).

v. minerals (oral zinc sulphate) (Serjeant 1970).

vi. pharmacologic stimulation of $\mathrm{HbF}$ synthesis agents (such as arginine butyrate) (Sher 1994);

\section{b. Topical pharmaceutical interventions:}

i. antibiotics and antiseptics (such as topical antibiotic (Baum 1987), collagen dressing (Reindorf 1989), natural honey (Okany 2004));

ii. growth factors and related (such as topical granulocytemacrophage colony-stimulating factor (GM-CSF) (Alikhan 2004; Mery 2004; Pieters 1995), RGD peptide matrix, 
Solcosery ${ }^{\circledR}$ (a tissue stimulating agent) (La Grenade 2003));

iii. steroids (such as cortisone - a potent anti-inflammatory) (Rice 1953);

iv. miscellaneous (such as topical opioids) (Ballas 2002).

\section{Non-pharmaceutical interventions}

\section{a. Non-pharmaceutical surgical interventions:}

i. reconstructive surgery (free flap transfer) (Spence 1985);

ii. cell therapy (e.g. human skin equivalent (Gordon 2003); allogeneic keratinocytes (Amini-Adle 2007));

\section{b. Non-pharmaceutical and non-surgical:}

i. laser therapy (e.g. InGaP (670 nm) laser) (Lucena 2007);

ii. miscellaneous (e.g. hyperbaric oxygen) (Espinosa 1992).

These interventions might occur alone or in combination. Recently, for example, a combination of treatment approaches (antibacterial agent, zinc oxide, bandages and debridement) have been proposed for improving the care of people with SCLUs (Schleucher 2007).

\section{Why it is important to do this review}

Even with rigorous conventional care, leg ulcers tend to be indolent and intractable, healing slowly over months or years (Ballas 2002; Minniti 2010). In the USA, the average duration of a SCLU has been reported to exceed three years (Wethers 1994) with recurrence rates ranging from $25 \%$ to $52 \%$ (Koshy 1989). The decreased quality of life, increased disability, absence from work and high utilization of health care resources can severely affect the lives of people with SCLUs (Cumming 2008; Halabi -Tawil 2008). This is an update of a previously published review (Martí-Carvajal 2012).

In this review, we assessed the clinical effectiveness and safety of interventions for treating leg ulcers in people with SCD.

\section{OB JECTIVES}

To determine whether any clinical interventions (used either alone or in combination) are effective and safe when treating leg ulcers in people with $S C D$.

\section{METHODS}

\section{Criteria for considering studies for this review}

\section{Types of studies}

Randomised controlled trials (RCTs).

\section{Types of participants}

People with all types of SCD who have been diagnosed with a leg ulcer and treated in a hospital or community setting, or both.

\section{Types of interventions}

Single or combination treatment regimen (with each treatment classified as pharmaceutical or non-pharmaceutical as detailed below) compared to either conventional care or another treatment regimen for leg ulcers in people with SCD.

\section{Pharmaceutical interventions}

Systemic interventions

- vascular drugs (such as pentoxifylline (blood viscosity-reducing agent), isoxsuprine hydrochloride ( $\beta$-adrenergic receptor stimulant), xanthinol nicotinate (vasodilator));

- antioxidant agents (such as L-carnitine);

- recombinant agents and related (such as recombinant human erythropoietin (erythropoiesis-stimulating agent which increases the haemoglobin levels), antithrombin III concentrate (potent coagulation inhibitor));

- growth factors: such as bosentan (a receptor endothelin receptor blocker);

- pharmacologic stimulation of HbF synthesis agents (such as arginine butyrate);

- oral zinc sulphate.

\section{Topical interventions}

- antibiotics and antiseptics (such as topical antibiotic, collagen dressing, natural honey);

- growth factors and related (such as topical granulocytemacrophage colony-stimulating factor (GM-CSF), RGD peptide matrix, Solcosery $\mathrm{l}^{\oplus}$ (a tissue stimulating agent));

- steroids (such as cortisone (a potent anti-inflammatory));

- dressing;

- debriding agents;

- compression;

- miscellaneous (such as topical opioids).

\section{Non-pharmaceutical interventions}

- reconstructive surgery (free flap transfer);

- cell therapy (e.g. human skin equivalent; allogeneic keratinocytes);

- laser therapy (e.g. InGaP (670 nm) laser);

- miscellaneous (e.g. hyperbaric oxygen).

\section{Types of outcome measures}

\section{Primary outcomes}

1. Incidence of complete closure (defined as $100 \%$ epithelization or skin closure without drainage)

2. Time to ulcer closure

3. Change in ulcer size (surface area or volume)

\section{Secondary outcomes}

1. Ulcer-free survival following treatment for SCLUs (free from leg ulcer recurrence)

2. Quality of life measures (based on any item from a validated scale, e.g. SF-36, EuroQoL, WHOQOL-BREF (Asnani 2009))

3. Incidence of amputation

4. Adverse events

a. any adverse event defined as "any untoward medical occurrence that may present during treatment with a pharmaceutical product but which does not necessarily have a causal relationship with this treatment" (Nebeker 2004).

b. adverse drug reactions defined as "a response to a drug which is noxious and uninitiated and which occurs at 
doses normally used in man for prophylaxis, diagnosis, or therapy of disease, or for the modification of physiologic functions" (Nebeker 2004).

\section{Search methods for identification of studies}

We searched for trials, irrespective of publication status (trials may be unpublished or published as an article, an abstract, or a letter), language or country. No limit was applied with respect to the period of follow-up.

\section{Electronic searches}

We identified relevant trials from the Cystic Fibrosis and Genetic Disorders (CFGD) Group's Haemoglobinopathies Trials Register using the terms: (sickle cell OR (haemoglobinopathies AND general)) AND leg ulcers.

Date of the last search of the Cochrane Cystic Fibrosis and Genetic Disorders Group Haemoglobinopathies Trials Register: 21 July 2014.

The CFGD Group's Haemoglobinopathies Trials Register is compiled from electronic searches of the Cochrane Central Register of Controlled Trials (CENTRAL) (updated each new issue of The Cochrane Library) and quarterly searches of MEDLINE. Unpublished work is identified by searching the abstract books of five major conferences: the European Haematology Association conference; the American Society of Hematology conference; the British Society for Haematology Annual Scientific Meeting; the Caribbean Health Research Council Meetings; and the National Sickle Cell Disease Program Annual Meeting. For full details of all searching activities for the register, please see the relevant section of the Cystic Fibrosis and Genetic Disorders Group Module.

We also searched the specialised register of the Cochrane Wounds Group (Cochrane Wounds Group). Date of the last search of the specialised register of the Cochrane Wounds Group: 18 September 2014.

We also searched the following resources using the keywords: (sickle cell OR (haemoglobinopathies AND general)) AND leg ulcers (to August 2012).

- Latin American and Caribbean Health Sciences Information System (LILACS) (from 1982);

- African Index Medicus (AIM);

- ISI Web of Knowledge (from 1985);

- Clinical Trials Search Portal of the World Health Organization;

- Food and Drug Administration;

- European Medicines Agency;

- Medicines and Healthcare Products Regulatory Agency;

- Scirus;

- CenterWatch;

- Sistema de Información Esencial en Terapéutica y Salud;

- Evidence in Health and Social Care;

- DailyMed.

\section{Searching other resources}

We also checked the reference lists of all the trials identified by the above methods. We contacted a number of key researchers (by email), asking whether they knew of studies assessing treatments for SCLUs in people with SCD.

\section{Data collection and analysis}

Data collection and analysis procedures are described below, and follow documented Cochrane Collaboration methodologies (Higgins 2011a).

\section{Selection of studies}

Two authors independently selected studies for inclusion, and extracted data. A third author was always included when two authors disagreed, with all disagreements resolved by group discussion.

\section{Data extraction and management}

We extracted the following groups of data:

- demographics (age, sex, country);

- characteristic of the ulcer (anatomic site, size, number of ulcers, presence of infection, how long the patient has had the ulcer);

- sickle cell genotype (SS, SC);

- phenotypic expression (e.g. total haemoglobin, fetal haemoglobin).

One review author, Jennifer M Knight-Madden, interviewed $\mathrm{Dr}$ Graham R. Serjeant, an author on four of the included RCTs (Baum 1987; La Grenade 1993; Serjeant 1977; Serjeant 1997) to clarify aspects of these trials that were unclear from the published trial reports.

Although potential interventions were broadly classed as pharmaceutical and non-pharmaceutical, we identified only pharmaceutical interventions and present results under two major groupings (systemic and topical). Given the clinical diversity of the included interventions, we do not regard it as appropriate to combine data for meta-analysis at this time.

For future updates, If we are able to find RCTs reporting these data, we plan to report our endpoints at between three and six months, and greater than six months: work from the Jamaican sickle cell cohort suggest that most leg ulcers take a minimum of between three and six months to heal (Serjeant 2005).

\section{Assessment of risk of bias in included studies}

We followed the domain-based evaluation for risk of bias in included RCTs (Higgins 2011a). All review authors independently assessed the risk of bias of the trials according to the Cochrane Handbook for Systemtic Reviews of Interventions (Higgins 2011a). The disagreements were resolved through discussion.

We assessed the following domains as low, unclear, or high risk of bias:

1. generation of allocation sequence;

2. allocation concealment;

3. blinding (of participants, personnel and outcome assessors);

4. incomplete outcome data;

5. selective reporting;

6. free of other bias. 


\section{Generation of allocation sequence (checking for possible selection bias)}

We described, for each included trial, whether the method used to generate the allocation sequence was reported in sufficient detail to allow an assessment of whether it produced comparable groups. We assessed the method as having one of the following risks of bias:

- low risk (any truly random process, e.g. random number table; computer random number generator);

- high risk (any non-random process, e.g. odd or even date of birth; hospital or clinic record number);

- unclear risk (if the trial was described as randomised, but the method used for the allocation sequence generation was not described).

\section{Allocation concealment (checking for possible selection bias)}

We described, for each included trial, whether the method used to conceal the allocation sequence was reported in sufficient detail and determined whether group allocation could have been foreseen in advance of, or during recruitment, or changed after assignment. We assessed the methods as having one of the following risks of bias:

- low risk (e.g. telephone or central randomisation; consecutively numbered sealed opaque envelopes);

- high risk (open random allocation; unsealed or non-opaque envelopes, alternation; date of birth);

- unclear risk (if the trial was described as randomised, but the method used to conceal the allocation was not described).

\section{Blinding or masking (checking for possible performance bias)}

We described, for each included trial, the methods used, if any, to blind study participants and personnel from knowledge of which intervention a participant received. We judged trials at low risk of bias if they were blinded, or if we judged that the lack of blinding could not have affected the results. We aimed to assess blinding separately for different outcomes or classes of outcomes. We assessed the methods as having one of the following risks of bias:

- low, high or unclear risk for participants;

- low, high or unclear risk for personnel;

- low, high or unclear risk for outcome assessors.

\section{Incomplete outcome data (checking for possible attrition bias through withdrawals, dropouts, protocol deviations)}

We assessed the methods as having one of the following risks of bias:

- low risk (the numbers and reasons for dropouts and withdrawals in all intervention groups were described or if it was specified that there were no dropouts or withdrawals);

- high risk (the number or reasons for dropouts and withdrawals were not described).

- unclear risk (the report gave the impression that there had been no dropouts or withdrawals, but this was not specifically stated);

We further examined the percentages of overall dropouts in each trial and per randomisation arm and aimed to evaluate whether an intention-to-treat analysis had been performed or could be performed from the published information.

\section{Selective reporting bias (reporting bias due to selective outcome reporting)}

We described, for each included trial, how we investigated the possibility of selective outcome reporting bias and what we found. We assessed the methods as having one of the following risks of bias:

- low risk (any one of the following: the study protocol is available and all of the study's pre-specified (primary and secondary) outcomes that are of interest in the review have been reported in the pre-specified way or the study protocol is not available but it is clear that the published reports include all expected outcomes, including those that were pre-specified (convincing text of this nature may be uncommon);

- high risk (any one of the following: not all of the study's prespecified primary outcomes have been reported; one or more primary outcomes is reported using measurements, analysis methods or subsets of the data (e.g. sub scales) that were not pre-specified; one or more reported primary outcomes were not pre-specified (unless clear justification for their reporting is provided, such as an unexpected adverse effect); one or more outcomes of interest in the review are reported incompletely so that they cannot be entered in a meta-analysis; the study report fails to include results for a key outcome that would be expected to have been reported for such a study);

- unclear risk (insufficient information to permit judgement of 'low risk' or 'high risk').

\section{Free of other bias (bias due to problems not covered elsewhere in the table)}

We described, for each included study, any important concerns we have about other possible sources of bias and made assessments as follows:

- low risk of bias (the trial appears to be free of other components that could put it at risk of bias);

- high risk of bias (there are other factors in the trial that could put it at risk of bias;

- unclear risk of bias (the trial may or may not be free of other components that could put it at risk of bias); e.g. ascertainment bias, bias in the presentation of data, design bias (Porta 2008). Please refer to the appendices for further details (Appendix 2).

\section{Overall risk of bias}

We made explicit judgements about whether studies are at high risk of bias, according to the criteria given in the Cochrane Handbook for Systemtic Reviews of Interventions (Higgins 2011a). In reference to the six domains above, we assessed the likely magnitude and direction of any bias and whether we considered it was likely to impact on the review findings.

Trials that achieved a 'low risk' assessment for adequate generation of allocation sequence, allocation concealment, blinding, handling of incomplete outcome data, and no selective outcome reporting, and that were without other risks of bias, were considered to be at an overall low risk of bias, while trials that were assessed as either 'high risk' or 'unclear risk' on the majority of domains were considered to be at a high risk of bias. We aimed to explore the 
impact of the level of bias through undertaking sensitivity analyses - see Sensitivity analysis.

\section{Measures of treatment effect}

For binary outcome measures (incidence of complete closure, adverse events), we calculated the risk ratio (RR) with 95\% confidence intervals (Cls) for each outcome. For continuous outcomes (change in ulcer size measured using surface area or volume), we calculated the mean difference with $95 \% \mathrm{Cls}$.

For the future update, if the search strategy finds new RCTs, we will plan to assess of treatment effect as follows:

- for binary outcome measures (incidence of complete closure, incidence of amputation, adverse events, and adverse drug reaction), we plan to calculate the risk ratio (RR) with 95\% confidence intervals ( $\mathrm{Cls})$ for each outcome.

- for continuous outcomes (quality of life), we will use the standardized mean difference with $95 \% \mathrm{Cls}$, since different scales may be used to measure quality of life. Change in ulcer size (surface area or volume) will be measured using a pooled estimate of treatment effect by calculating the mean difference with $95 \% \mathrm{Cls}$. If statistical information is missing (such as standard deviations), we will try to extract them from other relevant information in the paper, such as $\mathrm{P}$ values and $\mathrm{Cls}$

- for time-to-event outcome (time to ulcer closure and ulcer-free survival following treatment for SCLU), we plan to calculate the hazard ratios (HR) with 95\% Cls for each outcome.

\section{Unit of analysis issues}

This review has treated the participant as the unit of analysis. This is important as the meta-analytic techniques used assume independence between measurements, and more than one treated ulcer per participant would not be statistically independent. A result of ignoring this unit-of-analysis issue could be overly optimistic confidence intervals. We found six RCTs and of these, four used the ulcer as their unit of analysis (La Grenade 1993; Baum 1987; McMahon 2010; Serjeant 1977). For future updates, and if the review authors receive extra requested information from study authors, we plan to incorporate multiple ulcers per participant into our quantitative analyses using 'approximate analyses of clusterrandomised trials of meta-analysis', according to theCochrane Handbook for Systematic Reviews of Interventions (Higgins 2011b).

Due to problems with assuring a successful treatment 'washout' period, we do not consider cross-over trials an appropriate study design for assessing wound healing, and we have not included cross-over trials in this systematic review.

\section{Dealing with missing data}

For all included studies, we recorded the levels of participant attrition. Attrition rates were not stated in four of the six trial reports, and for these trials we approached the lead author for additional information on levels of missing data (Baum 1987; La Grenade 1993; Serjeant 1977; Serjeant 1997). This has allowed an intention-to-treat analysis for all included studies. For future updates, if necessary, we will seek full reports from authors where studies have been published in abstract form, presented at meetings or reported to the co-authors. Where information is missing or unclear, we will contact the primary investigator. In order to allow an intention-to-treat analysis, we grouped data by allocated treatment groups, irrespective of later exclusion (regardless of cause) or loss to follow-up.

\section{Assessment of heterogeneity}

For future updates, when more trials are included, we plan to test for heterogeneity between studies using a standard chi-squared test and 12 statistic (Higgins 2003). The chi-squared test is a statistical test for heterogeneity, whereas $1^{2}$ assesses the impact of heterogeneity on the meta-analysis. We will use the following 12 ranges to interpret heterogeneity:

- $0 \%$ to $40 \%$ : might not be important;

- 30\% to 60\%: may represent moderate heterogeneity;

- $50 \%$ to $90 \%$ : may represent substantial heterogeneity;

- $75 \%$ to $100 \%$ : considerable heterogeneity.

In the presence of substantial heterogeneity we plan to explore this heterogeneity by pre-specified subgroup analysis. We will also evaluate the extend of heterogeneity by visual inspection of the forest plot (Higgins 2011).

\section{Assessment of reporting biases}

Comprehensive searches were done by two authors to minimize publication and reporting biases. We compared the 'Methods' section of the full published paper to the 'Results' section to ensure that all outcomes which were measured, were reported. For future updates, If we are able to include 10 RCTs or more in a single metaanalysis, we will assess whether the review is subject to possible publication bias by using a funnel plot to graphically illustrate variability between trials. If asymmetry is detected, we will explore causes other than publication bias.

\section{Data synthesis}

No meta-analysis was undertaken in this review. For future updates, any meta-analyses will be performed separately for each intervention group (pharmaceutical systemic, pharmaceutical topical, non-pharmaceutical surgical, non-pharmaceutical nonsurgical). If the eligible trials are sufficiently homogenous, we will summarize their findings using a fixed-effect model. However, if we find statistical heterogeneity using the $\mathrm{I}^{2}$ statistic $\left(\mathrm{I}^{2}>50 \%\right)$ we will use a random-effects model (Higgins 2003; Higgins 2011). Clinical variability (variability in types of participants, interventions, or outcomes) may prevent us from pooling trials.

\section{Summary of findings tables}

We used the GRADE proposals to assess the quality of the body of evidence associated with the following outcomes: complete closure; change in ulcer size; and safety (total adverse events and related study treatment adverse events) (Guyatt 2011). We constructed summary of findings tables (SoF) using the GRADEPro software (Summary of findings for the main comparison; Summary of findings 2; Summary of findings 3; Summary of findings 4) (GRADEPro 2014). The GRADE approach appraises the quality of a body of evidence based on the extent to which one can be confident that an estimate of effect or association reflects the item being assessed. The quality of a body of evidence considers within-study risk of bias (methodological quality), the directness of the evidence, heterogeneity of the data, precision of effect estimates and risk of publication bias (Balshem 2011; Guyatt 2011a; Guyatt 2011b; 
Guyatt 2011c; Guyatt 2011d; Guyatt 2011e; Guyatt 2011f; Guyatt 2011g; Guyatt 2011h; Guyatt 2012).

We would have used (and will apply these for future updates, if possible) the principles of the GRADE system to assess the quality of the body of evidence associated with others outcomes of this review which were not assessed by the included RCTs in this review: time to ulcer closure; ulcer-free survival following for SCLUs (free from leg ulcer recurrence); quality of life; and incidence of amputation.

\section{Subgroup analysis and investigation of heterogeneity}

For future updates, if we find clinical heterogeneity, we plan to conduct subgroup analyses as follows:

1. SS type versus SC type (Appendix 1);

2. follow-up duration.

These subgroup analyses will be only conducted for primary outcomes.

\section{Sensitivity analysis}

No sensitivity analyses were undertaken in this review. If sufficient data had been available, we would have used the following procedures (and will apply these for future updates, if possible). We would have compared RCTs with high versus low methodological quality (studies classified as having a 'low risk of bias' versus those identified as having a 'high risk of bias') and RCTs that performed intention-to treat versus per-protocol analyses (Higgins 2011).

For future updates, we will also evaluate the risk of attrition bias, as estimated by the percentage of participants lost. Trials with a total attrition of more than $30 \%$ or where differences between the groups exceed $10 \%$, or both, would be excluded from meta-analysis but included in the review (Higgins 2011a).

\section{RE S U L T S}

\section{Description of studies}

\section{Results of the search}

We identified 88 references using our search strategy (see Figure 2 for search result details). Six RCTs met our inclusion criteria (Baum 1987; La Grenade 1993; McMahon 2010; Serjeant 1977; Serjeant 1997; Wethers 1994). These RCTs were published between 1977 and 2010, four in Jamaica (Baum 1987; La Grenade 1993; Serjeant 1977; Serjeant 1997) and two in The United States of America (McMahon 2010; Wethers 1994). There were 250 ulcers studied among 198 participants (trial sample sizes ranged from 15 to 55 participants). A detailed description of the included trials is provided in the Characteristics of included studies table.

\section{Figure 2. Flowchart of last search of the Group's Trials Register: 25 May 2012.}
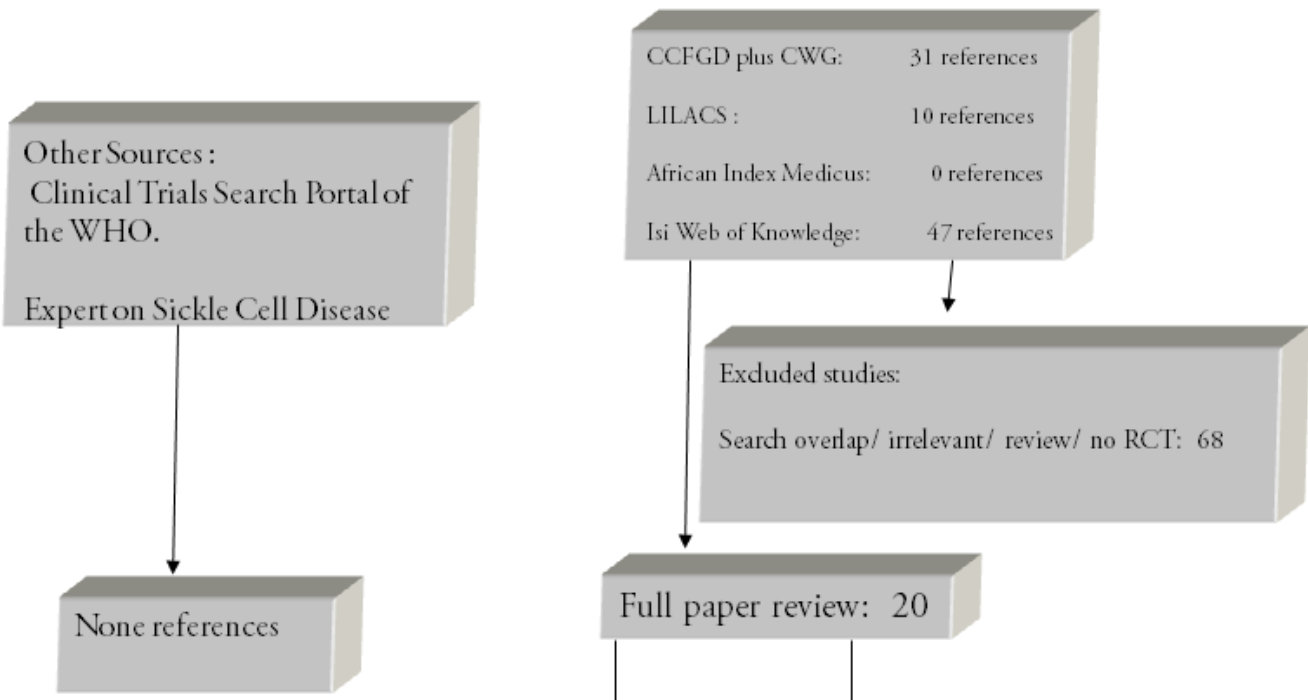

Full paper review: 20

Included studies: 6 ( 12 publications)

Baum 1987; La Grenade 1993; McMaahon 2010; Serjeant 1977; Serjeant 1997; Wethers 1994



CCFHDG: Cochrane Cystic Fibrosis and Genetic Disorders group.

CWG: Cochrane Wound group. 


\section{Included studies}

The six included RCTs report the following baseline characteristics (Baum 1987; La Grenade 1993; McMahon 2010; Serjeant 1977; Serjeant 1997; Wethers 1994).

\section{Clinical characteristics}

\section{Genotype of SCD}

Two RCTs only included patients with HbSS (Baum 1987; La Grenade 1993). Three RCTs included patients with HbSS, HbSC, HbSS-O (Arab), HbS $\beta$ thalassaemia, HbSC Harlem, HbS (Serjeant 1977; Serjeant 1997; Wethers 1994). One trial reported 92.3\% (24 out of 26) of the participants with HbSS (McMahon 2010).

\section{Leg ulceration duration, leg ulcer diameter on entry to the trial and} number of ulcer per patient

Two RCTs mentioned leg ulceration duration at baseline (Baum 1987; Wethers 1994). Five RCTs mentioned leg ulcer diameter on trial entry (Baum 1987; La Grenade 1993; McMahon 2010; Serjeant 1997; Wethers 1994). One trial excluded patients with large leg ulcers, but did not define the limits of inclusion (Baum 1987). Two RCTs reported baseline ulcer size using median area (Baum 1987; La Grenade 1993). Two RCTs reported baseline ulcer size using mean area (McMahon 2010; Wethers 1994). Three RCTs reported the number of ulcers per patient (Baum 1987; McMahon 2010; Serjeant 1977). See Characteristics of included studies for details.

\section{Intervention characteristics}

\section{Type of intervention}

Each trial investigated a different intervention to treat SCLUs. Baum assessed topical antibiotics (Baum 1987), La Grenade assessed Solcoseryl ${ }^{\oplus}$ and DuoDerm as two arms of a three-arm trial (La Grenade 1993), McMahon assessed arginine butyrate (McMahon 2010), Serjeant assessed isoxsuprine (Serjeant 1977) and propionylL-carnitine (Serjeant 1997), and Wether assessed RGD peptide matrix (Wethers 1994).

\section{Administration route of intervention}

Two RCTs used an oral administration (Serjeant 1977; Serjeant 1997). Three RCTs used topical interventions (Baum 1987; La Grenade 1993; Wethers 1994). One RCT used an intravenous intervention (McMahon 2010).

\section{Outcome characteristics}

Three RCTs explicitly stated their primary outcomes (Baum 1987; La Grenade 1993; Wethers 1994). The primary outcomes were pain (Baum 1987), healing rate (La Grenade 1993) and changes in per cent ulcer closure (Wethers 1994). According to Dr Graham Serjeant, interviewed by one author of this review (JKM), 'ulcer area-change' was the primary outcome assessed in four trials that he was involved in (Baum 1987; La Grenade 1993; Serjeant 1977; Serjeant 1997). No RCTs explicitly described their secondary outcomes. These outcome measurements or definitions, as they were shown in each RCT, are listed within an appendix (Appendix 3).

\section{Methodology characteristics}

\section{Units of randomisation and of analysis}

Five RCTs declared participants as the unit of randomisation (Baum 1987; McMahon 2010; Serjeant 1977; Serjeant 1997; Wethers 1994). One RCT chose leg ulcers as the unit of randomisation (La Grenade 1993).

However, from the published papers, it was clear that two RCTs used participants as the unit of analysis (Serjeant 1997; Wethers 1994) and that four reported ulcers as the unit of analysis (La Grenade 1993; McMahon 2010; Serjeant 1977; Baum 1987). See the appendices for a summary of the unit of randomisation and the unit of analysis (Appendix 4). For those trials with ulcer as the unit of analysis, data have been narratively reported. We have contacted trial authors requesting further information that would allow us to accommodate the increased correlation that comes from multiple ulcers 'clustered' within an individual into our meta-analysis. If received, we would use this information in a future update of the review.

\section{Number of comparison groups}

Five RCTs were conducted comparing two groups (Baum 1987; McMahon 2010; Serjeant 1977; Serjeant 1997; Wethers 1994). One RCT was conducted comparing three groups (La Grenade 1993).

\section{A priori sample size estimation}

One RCT was conducted with an a priori sample size estimation (Serjeant 1997). Five RCTs did not report information on sample size calculation a priori (Baum 1987; La Grenade 1993; McMahon 2010; Serjeant 1977; Wethers 1994). Dr Graham Serjeant (04 February 2011) has confirmed that four of the trials were not conducted using sample size a priori (Baum 1987; La Grenade 1993; Serjeant 1977; Serjeant 1997).

\section{Follow-up period}

The follow-up period ranged between two and six months: eight weeks (Baum 1987); ten weeks (Wethers 1994); twelve weeks (La Grenade 1993; McMahon 2010; Serjeant 1997); and six months (Serjeant 1977).

\section{Description of the inclusion and exclusion criteria}

One RCT did not describe the inclusion criteria (Serjeant 1977) and three RCTs did not describe the exclusion criteria (La Grenade 1993; Serjeant 1977; Serjeant 1997).

\section{Multiple trials reports}

The search strategy identified three included RCTs with multiple preliminary reports (Baum 1987; McMahon 2010; Wethers 1994).

\section{Excluded studies}

Eight studies were excluded (Afifi 1979; Cacciola 1990b; Lucena 2007; Neves 2010; Okany 2004; Paggiaro 2010; Serjeant 1970; Sawyer 1979). Overall, the majority of these studies were non-RCT or case reports. See the Characteristics of excluded studies table for a detailed account of the reasons for exclusion. 


\section{Risk of bias in included studies}

None of the included RCTs were graded as having an overall low risk of bias. The risk of bias of all domains listed above for all included trials are summarised in Figure 3 and Figure 4.

Figure 3. Risk of bias graph: review authors' judgements about each risk of bias domain presented as percentages across all included studies

Random sequence generation (selection bias)

Allocation concealment (selection bias)

Blinding of participants and personnel (performance bias)

Blinding of outcome assessment (detection bias)

Incomplete outcome data (attrition bias)

Selective reporting (reporting bias)

Other bias

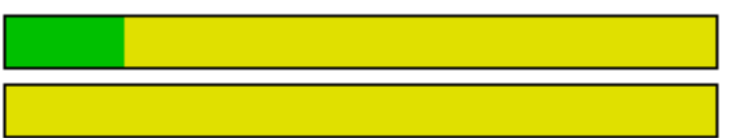

L

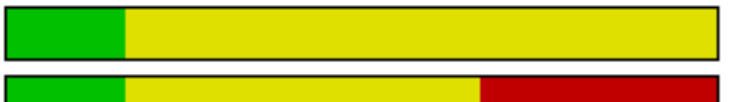

$$
\text { L }
$$
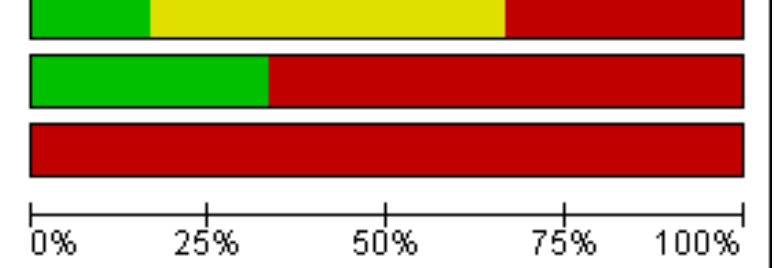
Figure 4. Risk of bias summary: review authors' judgements about each risk of bias domain for each included study

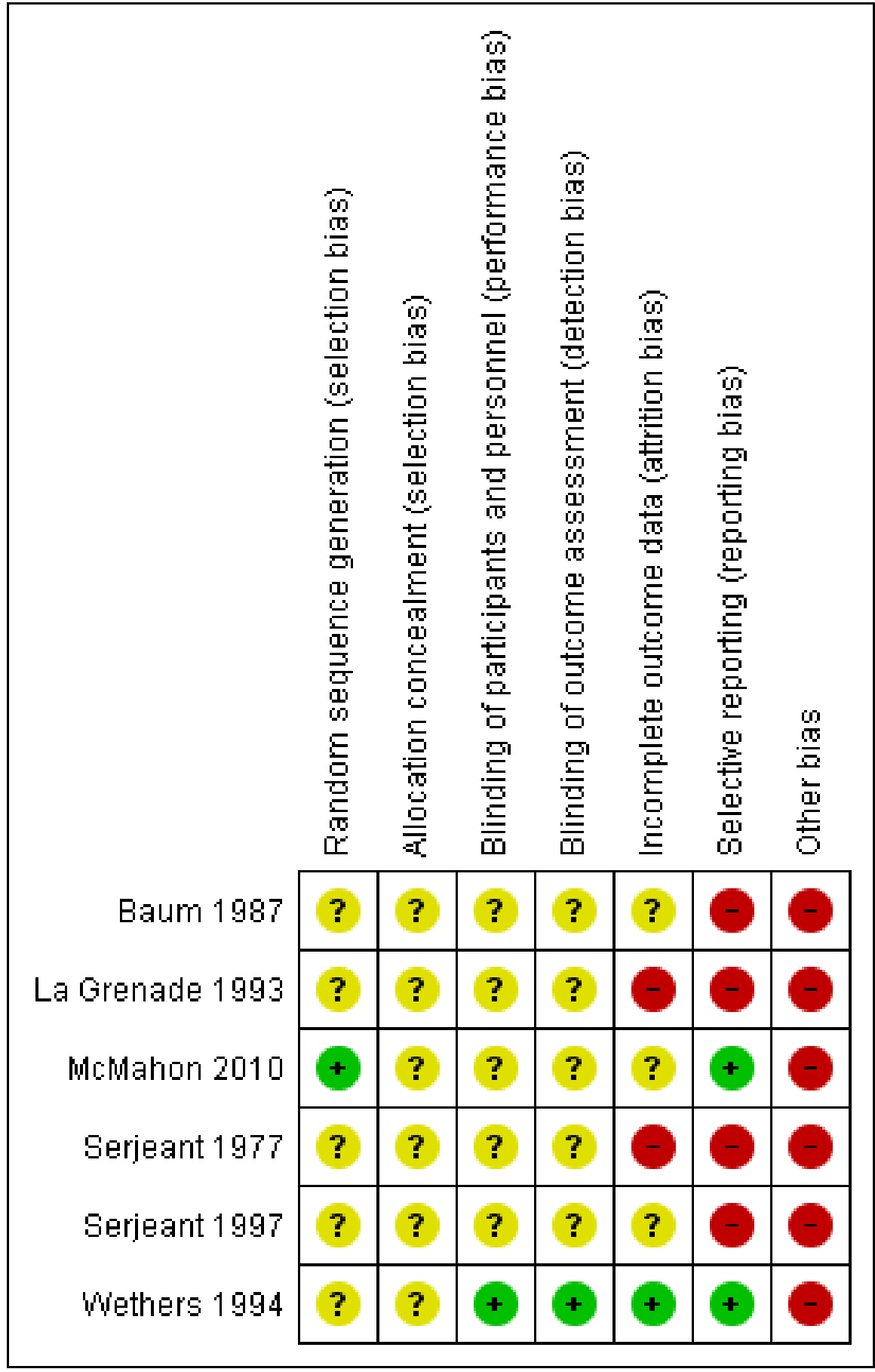

\section{Allocation}

One RCT used an adequate method for sequence generation (graded as low risk) (McMahon 2010). We assessed five RCTs as having an unclear risk of bias in relation to the method used for generating the allocation sequence (Baum 1987; La Grenade 1993; Serjeant 1977; Serjeant 1997; Wethers 1994). No information was reported on allocation concealment by any of the included trials (Baum 1987; La Grenade 1993; McMahon 2010; Serjeant 1977; Serjeant 1997; Wethers 1994). See Characteristics of included studies for details.

\section{Blinding}

We assessed participant and personnel blinding separately. Three RCTs were described within the published papers as blinded trials (Serjeant 1977; Serjeant 1997; Wethers 1994). We judged one trial to have an adequate blinding process (low risk) (Wethers 1994). No information was reported about this domain in the remaining five trials (unclear risk) (Baum 1987; La Grenade 1993; McMahon 2010; Serjeant 1977; Serjeant 1997). See Characteristics of included studies for details. 


\section{Incomplete outcome data}

One RCT was assessed as having adequately reported outcome data (low risk) (Wethers 1994). Three RCTs were assessed as having an unclear risk in this domain (Baum 1987; McMahon 2010; Serjeant 1997), and two as having a high risk of bias in this domain (La Grenade 1993; Serjeant 1977). See Characteristics of included studies for details.

\section{Selective reporting}

Two RCTs show adequate reporting (graded as low risk) (McMahon 2010; Wethers 1994). The remaining four RCTs were assessed as having a high risk of bias for this domain (Baum 1987; La Grenade 1993; Serjeant 1977; Serjeant 1997). See Characteristics of included studies for details.

\section{Other potential sources of bias}

All of the included RCTs show some type of bias (ascertainment bias, bias in the presentation of data, design bias). See Characteristics of included studies for details. See Appendix 2 for bias definitions.

\section{Effects of interventions}

See: Summary of findings for the main comparison Isoxuprine compared to placebo for leg ulcer in people with sickle cell disease; Summary of findings 2 Arginine butyrate plus standard local care compared to standard local care for sickle cell in people with sickle cell disease; Summary of findings $\mathbf{3} \mathrm{L}$-carnitine compared to placebo for leg ulcer in people with sickle cell disease; Summary of findings 4 RGD peptide matrix compared to placebo for leg ulcer in people with sickle cell disease

Six RCTs were conducted for treating leg ulcers in people with SCD (Baum 1987; La Grenade 1993; McMahon 2010; Serjeant 1977; Serjeant 1997; Wethers 1994). The results are based on five RCTs (La Grenade 1993; McMahon 2010; Serjeant 1977; Serjeant 1997; Wethers 1994) as Baum did not report on any of the outcomes predefined in our protocol (Baum 1987). See Summary of findings for the main comparison; Summary of findings 2; Summary of findings 3; Summary of findings 4 . Results were based on 168 participants with 210 ulcers. All RCTs assessed pharmaceutical interventions. Due to the differences in the modes of action of the pharmaceutical interventions used in the trials, we regarded it as inappropriate to combine the data available. Please note, as referred to above, for those trials where ulcers were the unit of analysis (instead of the participant), data have been narratively reported and not included in the meta-analysis (La Grenade 1993; McMahon 2010; Serjeant 1977).

\section{Primary outcomes}

\section{Pharmaceutical interventions}

\section{Systemic interventions}

Three trials investigated systemic interventions (McMahon 2010; Serjeant 1977; Serjeant 1997).

\section{Primary outcomes}

1. Incidence of complete closure (defined as $100 \%$ epithelization or skin closure without drainage)

- Vascular drugs
Isoxsuprine

One trial (involving 30 patients as the unit of randomisation and 46 ulcers as the unit of analysis) compared isoxsuprine with placebo (Serjeant 1977). This trial reported on: healed ulcers (23.9\% (11 out of 46: 7 in the isoxsuprine group versus 4 in the control group); improved ulcers (36.9\% (17 out of 46: 8 in the isoxsuprine group versus 9 in the control group); no changes in the ulcers (15.2\% (7 out of 46: 5 in the isoxsuprine group versus 2 in the control group); and deteriorated ulcers (23.9\% (11 out of 46: 8 in the isoxsuprine group versus 3 in the control group) (Serjeant 1977).

- Pharmacologic stimulation of HbF synthesis agents

Arginine butyrate

One trial (involving 23 patients as the unit of randomisation and 62 ulcers as the unit of analysis) assessed arginine butyrate plus standard local care versus standard local care. This trial reported a complete closure incidence of $30 \%$ (11 out of 37 ) in the arginine butyrate group compared with $8 \%$ ( 2 out of 25 ) in the control group at 12 weeks of trial $(P=0.056)($ McMahon 2010).

\section{Time to ulcer closure}

This outcome was not reported on in any of the RCTs.

\section{Change in ulcer size (surface area or volume)}

- Vascular drugs

Isoxsuprine

One trial of 54 ulcers assessing this drug reported that a mean overall change in six-month period was $-1.4 \mathrm{~cm}^{2} / \mathrm{ulcer}$ in the treatment group and $+0.7 \mathrm{~cm}^{2}$ in the controls (Serjeant 1977).

\section{- Antioxidant agents}

L-carnitine

One trial (Serjeant 1997) of 15 participants reported this outcome over the course of the trial with a non-statistically significant change in ulcer size noted in the L-carnitine group compared with those non-receiving L-carnitine, MD: $-3.90 \mathrm{~cm}^{2}, 95 \% \mathrm{Cl}-13.44$ to 5.64 $(P=0.42)$. (Analysis 1.1).

\section{- Pharmacologic stimulation of HbF synthesis agents}

Arginine butyrate

One trial reported that the mean decrease in ulcer area was nearly four times greater for the treatment arm in the $10 \mathrm{~cm}^{2}$ to $40 \mathrm{~cm}^{2}$ category ( $53 \%$ versus $12 \%$ closure) and nearly twice as many ulcers in the treatment arm healed in the larger than $40 \mathrm{~cm}^{2}$ group (43\% versus $23 \%$ in the control arm) (McMahon 2010).

\section{Secondary outcomes}

1. Ulcer-free survival following treatment for SCLU (free from leg ulcer recurrence)

This outcome was not reported on in any of the RCTs.

\section{Quality of life measures (based on any item from a validated scale, e.g. SF-36, EurOQOL, WHOQOL-BREF)}

This outcome was not reported on in any of the RCTs.

\section{Incidence of amputation}

This outcome was not reported on in any of the RCTs. 


\section{Adverse events}

\section{- Pharmacologic stimulation of HbF synthesis agents}

Arginine butyrate (McMahon 2010).

One trial reported that no serious adverse events were reported to be directly related to the study drug (McMahon 2010). Prior to arginine butyrate treatment on this study, port-a-cath infections did occur in two participants who had ports for their standard sickle cell care.

\section{Topical pharmaceutical interventions}

Three trials investigated topical interventions (Baum 1987; La Grenade 1993; Wethers 1994). The results are based on two RCTs (La Grenade 1993; Wethers 1994)

\section{Primary outcomes}

\section{Incidence of complete closure (defined as $\mathbf{1 0 0} \%$ epithelization or} skin closure without drainage)

\section{- Growth factors and related}

One trial of 55 participants and 14 events reported this outcome over the course of the trial with a non-statistically significant increase in complete closure noted in the RGD peptide matrix group compared with the placebo group, RR $0.40,95 \% \mathrm{Cl} 0.15$ to $1.04(\mathrm{P}=$ 0.06) (Wethers 1994) (Analysis 2.1).

\section{Time to ulcer closure}

This outcome was not reported on in any of the RCTs.

\section{Change in ulcer size}

- Growth factors and related

One trial reported this outcome over the course of the trial with a statistically significant change in ulcer size noted in the RGD peptide matrix group compared with the placebo group, MD $6.60 \mathrm{~cm}^{2}(95 \%$ $\mathrm{Cl} 5.51$ to 7.69$)(\mathrm{P}<0.001)$ (Wethers 1994) (Analysis 2.2).

A further trial of 32 participants and 49 ulcers reported this outcome over the course of the trial with a non-statistically significant change in ulcer size noted in the Solcoseryl ${ }^{\circledR}$ and hydrocolloid dressing compared with those non-receiving Solcoseryl ${ }^{\oplus}$ and hydrocolloid dressing (La Grenade 1993). It was reported that "The mean difference in reduction of ulcer area between Solcoseryl ${ }^{\circledR}$ and controls was $7.1 \mathrm{~cm}^{2}$ (95\% IC -0.7 to 14.9), and between hydrocolloid dressing and controls was $4.2 \mathrm{~cm}^{2}(95 \% \mathrm{Cl}-3.6$ to 12.0). The mean difference in relative ulcer size between Solcosery $l^{\circledR}$ and controls was $28.3 \mathrm{~cm}^{2}(95 \% \mathrm{Cl}-1.9$ to 58.5$)$, and between hydrocolloid dressing and controls was $-1.3 \mathrm{~cm}^{2}(95 \% \mathrm{Cl}-31.5$ to 28.9)".

\section{Secondary outcomes}

1. Ulcer-free survival following treatment for SCLU (free from leg ulcer recurrence)

This outcome was not reported on in any of the RCTs.

\section{Quality of life measures (based on any item from a validated scale,} e.g. SF-36, EuroQoL, WHOQOL-BREF)

This outcome was not reported on in any of the RCTs.

\section{Incidence of amputation}

This outcome was not reported on in any of the RCTs.

\section{Adverse events}

- Growth factors and related

One trial of 55 participants and 33 events reported the total occurrence of adverse events over the course of the trial with a nonstatistically significant increase of this outcome noted in the RGD peptide matrix group compared with the placebo group, RR 0.76 (95\% $\mathrm{Cl} 0.50$ to 1.17$)(\mathrm{P}=0.21)$ (Wethers 1994) (Analysis 2.3). Wethers (for 33 participants and 5 events) also reported the treatmentrelated adverse event over the course of the trial, which showed a non-statistically significant increase of this outcome in the RGD peptide matrix group compared with the placebo group,RR 1.41 (95\% $\mathrm{Cl} 0.27$ to 7.38$)(\mathrm{P}=0.68)$ (Wethers 1994) (Analysis 2.3).

One trial assessing Solcosery $\mathrm{l}^{\oplus}$ and hydrocolloid dressing reported that "Solcoseryl ${ }^{\otimes}$ was well tolerated as was Eusol except for a burning sensation reported by several patients (La Grenade 1993). Hydrocolloid dressing was not well tolerated, four patients expressing dislike because of the large volume of exudate which was smelly and required daily changes of dressing in the early part of the study, and two of these defaulted".

\section{DISCUSSION}

\section{Summary of main results}

This review of interventions for treating leg ulcers in people with SCD included six studies (198 participants with 250 ulcers) which were grouped as systemic pharmaceutical interventions (L-carnitine (Serjeant 1997), arginine butyrate (McMahon 2010), isoxsuprine hydrochloride (Serjeant 1977))

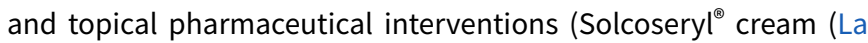
Grenade 1993), RGD peptide dressing (Wethers 1994), and topical antibiotics (Baum 1987). One trial was included but not reported any pre-specified outcome in this Cochrane review (Baum 1987). Of these, RGD peptide dressing was effective in reducing the size of treated ulcers compared with placebo (Wethers 1994). The evidence for the use of interventions to treat people with sickle cell disease is not strong. Although there is some encouraging evidence for the use of RGD peptide matrix to reduce ulcer size, given the inadequacies with the associated trial reports, we currently feel that further confirmatory work is needed. Trials had a high risk of bias and failed to show beneficial effects. Please refer to the following tables for details (Summary of findings for the main comparison; Summary of findings 2; Summary of findings 3; Summary of findings 4).

\section{Overall completeness and applicability of evidence}

This review provides inconclusive evidence on the assessed interventions due to both heterogeneity between trials, and inadequate information provided by trial reports (Hopewell 2010). During this review, we have identified the following issues, which we feel are particularly relevant to consider as further work is planned. Generally, heterogeneity between trials prevented the pooling of results, with the main areas of variation between trials being differences in outcome definition, and inconsistency between unit of randomisation and unit of analysis (Appendix 4). In this regard, it has been recently suggested that trials adopt an 
agreed set of core outcomes for each medical condition (Clarke 2007). This approach could help to reduce the impact of outcome reporting bias (Kirkham 2010). In particular, a lack of reported inclusion and exclusion criteria and a lack of reported outcome definitions hampered the ability to compare trials (Appendix 3 ).

\section{Quality of the evidence}

The main source of bias in the included studies was the lack of detail in describing the generation of the randomisation sequences or the allocation concealment (Baum 1987; La Grenade 1993; Serjeant 1977; Serjeant 1997; Wethers 1994). We interviewed an author who was on four of the six included studies, who provided information on outstanding details. Trials also lacked detail about their blinding processes. The review authors' assessment of the risk of bias of the included studies has been described previously and a summary can be found in Figure 3 and Figure 4. The studies were classified as having a high risk of bias. Uncertainty remains about possible harms from the interventions, due to a lack of information presented on safety data.

\section{Potential biases in the review process}

In the process of performing a systematic review, there is a group of biases called significance-chasing biases (loannidis 2010). These includes publication bias, selective outcome reporting bias, selective analysis reporting bias, and fabrication bias (loannidis 2010). Publication bias represents a major threat to the validity of systematic reviews, particularly in reviews such as this one that include small trials. However, we believe that this Cochrane review has a low risk of publication bias due to the thorough trial search process. We contacted the main author of four included RCTs. Selective outcome reporting bias operates through suppression of information on specific outcomes and has similarities to study publication bias, in that 'negative' results remain unpublished (Ioannidis 2010). This Cochrane review found that four out of the six included RCTs have high risk of selective outcome reporting (Baum 1987; La Grenade 1993; Serjeant 1977; Serjeant 1997).

\section{AUTHORS' CONCLUSIONS}

\section{Implications for practice}

This Cochrane review of interventions for treating leg ulcers in people with sickle cell disease provides some evidence of effectiveness for treatment with RGD peptide (Wethers 1994). However, this trial had a generally high risk of bias due to inadequacies in the trial reports. We recommend that readers interpret the trial results with caution. There was no reported information on the safety of these interventions.

\section{Implications for research}

This systematic review has highlighted a need for well-designed, high-quality randomised trials to assess the benefits and harms of interventions to improve the healing of the leg ulcer in patients with SCD. The RCTs should include outcomes such as incidence of complete closure, ulcer-free survival following treatment for SCLU, time to ulcer closure, change in ulcer size (surface area or volume), quality of life measures and adverse events. Future trials should be conducted by independent researchers and reported according to the Consolidated Standards of Reporting Trials (CONSORT) guidelines (Ioannidis 2004; Moher 2010) and using the Foundation of Patient-Centered Outcomes Research recommendations (Anonymous 2012; Gabriel 2012).

\section{ACKNOWLEDGEMENTS}

We want to express our gratitude to the following people, whose help made it possible to improve the quality of this review: Tracey Remmington, Dr lan Hambleton, Dr Graham Serjeant, Dr E. Vichinsky, Professor C. Johnson, Dame Professor Sally Davies, Dr Oswald Castro, Dr R.F. Machado, Dr A. Almeida, Professor M. Steinberg and Dr Samir Ballas.

We also want express our gratitude the Cochrane Wounds Group Wounds Group. 


\section{R E F E R E N C E S}

\section{References to studies included in this review}

Baum 1987 \{published data only\}

* Baum KF, MacFarlane DE, Maude GH, Serjeant GR. Topical antibiotics in chronic sickle cell leg ulcers. Transactions of the Royal Society of Tropical Medicine and Hygiene 1987;81(5):847-9. [PUBMED: 2835836]

Macfarlane DE, Baum KF, Maude GH, Serjeant GR. Topical antibiotics in chronic sickle-cell leg ulcers. West Indian Medical Journal 1986;35 Suppl:46-7.

\section{La Grenade 1993 \{published data only\}}

La Grenade L, Thomas PW, Serjeant GR. A randomized controlled trial of solcoseryl and duoderm in chronic sickle-cell ulcers. West Indian Medical Journal 1993; Vol. 42, issue 3:121-3. [PUBMED: 8273321]

\section{McMahon 2010 \{published data only\}}

Koshy M, Askin M, McMahon L, Adams-Graves P, Halloway L, Faller DV, et al. Arginine butyrate in sickle cell leg ulcers: interim findings of a phase II trial [abstract]. The National Sickle Cell Disease Program Annual Meeting Conference Proceedings. 2000:175a.

Koshy M, Askin M, McMahon L, Adams-Graves P, Halloway L, Faller DV, et al. Arginine butyrate in sickle cell leg ulcers: interim findings of a randomized phase II trial [abstract]. The National Sickle Cell Disease Program Annual Meeting Conference Proceedings. 2001:Abstract no: 124.

Koshy M, Edinburgh L, McMahon L, Adams-Graves P, Halloway L, Faller DV, et al. Arginine butyrate in sickle cell leg ulcers: interim findings of a phase II trial [abstract]. Blood 1999;Suppl:417a.

* McMahon L, Tamary H, Askin M, Adams-Graves P, Eberhardt RT, Sutton M, et al. A randomized phase II trial of Arginine Butyrate with standard local therapy in refractory sickle cell leg ulcers. British Journal of Haematology 2010;151(5):516-24. [PUBMED: 20955402]

McMahon LC, Askin M, Koshy M, Tamary H, Atweh GF, AdamGraves $\mathrm{P}$, et al. A phase II trial of arginine butyrate in refractory sickle cell leg ulcers [abstract]. Blood 2002;100 (11 Pt 1 of 2):10a-1a.

\section{Serjeant 1977 \{published data only\}}

Serjeant GR, Howard C. Isoxsuprine hydrochloride in the therapy of sickle cell leg ulceration. West Indian Medical Journal 1977;26(3):164-6. [PUBMED: 333769]

\section{Serjeant 1997 \{published data only\}}

Serjeant BE, Harris J, Thomas P, Serjeant GR. Propionyl-Lcarnitine in chronic leg ulcers of homozygous sickle cell disease: a pilot study. Journal of the American Academy of Dermatology 1997;37(3 Pt 1):491-3. [PUBMED: 9308570]

\section{Wethers 1994 \{published data only\}}

Ramirez GM, Wethers DL, Koshy M, Steinberg MH, Phillips G Jr, Siegel RS, et al. Accelerated healing of chronic sickle cell leg ulcers treated with a RGD matrix. The National Sickle Cell Disease Program Annual Meeting Conference Proceedings. 1994.

* Wethers DL, Ramirez GM, Koshy M, Steinberg MH, Phillips G Jr, Siegel RS, et al. Accelerated healing of chronic sickle-cell leg ulcers treated with RGD peptide matrix. RGD Study Group. Blood 1994;84(6):1775-9. [PUBMED: 8080985 ]

\section{References to studies excluded from this review}

Afifi 1979 \{published data only\}

Afifi AM, Adnan M, Taha M, Amasha ME. Xanthinol nicotinate in the management of leg ulcers associated with haemoglobinopathies. Current Medical Research and Opinion 1979, issue 5:309-13. [PUBMED: 80156092]

Cacciola 1990b \{published data only\}

Cacciola E, Giustolisi R, Musso R, Longo A, Cacciola E. Antithrombin III concentrate for treatment of chronic leg ulcers in sickle cell-beta thalassemia: a pilot study. Annals of Internal Medicine 1990;111(6):534-6. [PUBMED: 2774375]

\section{Lucena 2007 \{published data only\}}

Lucena A, Souza K, Anselmo C, Nascimento A, Araújo A. InGaP $(670 \mathrm{~nm})$ laser use in the leg ulcer healing in patients with sickle cell anemia [O uso do laser de ingap $(670 \mathrm{~nm})$ na cicatrização de úlceras de perna em pacientes com anemia falciforme]. Anais da Faculdade de Medicina da Universidade Federal de Pernambuco 2007;52(1):45-50. [LILACS ID: 495328]

\section{Neves 2010 \{published data only\}}

Neves AF, Martins A, Queiroz AMM, Thomé ED, Queiroz APA, Lobo CLC. Evaluation of the topical application of opioid analgesia for a leg ulcer of a sickle cell disease patient [Avaliação da analgesia de opioide tópico em úlcera de perna de paciente falcêmico]. Revista Brasileira de Hematologia e Hemoterapia 2010;32(2):123-5. [LILACS ID: lil-553486]

Okany 2004 \{published data only\}

Okany CC, Atimomo CE, Akinyanju OO. Efficacy of natural honey in the healing of leg ulcers in sickle cell anaemia. The Nigerian Postgraduate Medical Journal 2004;11(3):179-81. [PUBMED: 15505645]

\section{Paggiaro 2010 \{published data only\}}

Paggiaro AO, de Carvalho VF, Fonseca GHH, Doi A, Ferreira MC. Negative pressure therapy for complex wounds in patients with sickle-cell disease: a case study. Ostomy Wound Management 2010;56(8):62-7. [IDS Number: 644CO ]

\section{Sawyer 1979 \{published data only\}}

Sawyer PN, Haque S, Reddy K, Sophie Z, Feller J. Wound healing effects of debrisan on varicose, postoperative, decubitus, and sickle-cell ulcers in man. Vascular Surgery 1979; Vol. 13, issue 4:251-6. 
Serjeant 1970 \{published data only\}

Serjeant GR, Galloway RE, Gueri MC. Oral zinc sulphate in sicklecell ulcers. Lancet 1970; Vol. 2, issue 7679:891-2. [PUBMED: 4097279]

\section{Additional references}

\section{Akinsheye 2010}

Akinsheye I, Klings ES. Sickle cell anemia and vascular dysfunction: the nitric oxide connection. Journal of Cellular Physiology 2010;224(3):620-5. [PUBMED: 20578237]

\section{Akinyanju 1979}

Akinyanju O, Akinsete I. Leg ulceration in sickle cell disease in Nigeria. Tropical and Geographical Medicine 1979;31:87-91. [PUBMED: 483376]

\section{al-Momen 1991}

al-Momen AK. Recombinant human erythropoietin induced rapid healing of a chronic leg ulcer in a patient with sickle cell disease. Acta Haematologica 1991;86:46-8. [PUBMED: 1950363]

\section{Alexander 2004}

Alexander N, Higgs D, Dover G, Serjeant GR. Are there clinical phenotypes of homozygous sickle cell disease?. British Journal of Haematology 2004;126:606-11. [PUBMED: 15287956]

\section{Alikhan 2004}

Alikhan MA, Carter G, Mehta P. Topical GM-CSF hastens healing of leg ulcers in sickle cell disease. American Journal of Hematology 2004;76:192. [PUBMED: 15164391]

\section{Alleyne 1977}

Alleyne SI, Wint E, Serjeant GR. Social effects of leg ulceration in sickle cell anemia. Southern Medical Journal 1977;70:213-4. [PUBMED: 841405]

\section{Amini-Adle 2007}

Amini-Adle M, Auxenfants C, Allombert-Blaise C, DerooBerger MC, Ly A, Jullien D, et al. Rapid healing of long-lasting sickle cell leg ulcer treated with allogeneic keratinocytes. Journal of the European Academy of Dermatology and Venereology 2007;21:707-8. [PUBMED: 17448004]

\section{Ankra-Badu 1992}

Ankra-Badu GA. Sickle cell leg ulcers in Ghana. East African Medical Journal 1992;69:366-9. [PUBMED: 1396190]

\section{Anonymous 2012}

Anonymous. Methodological standards and patientcenteredness in comparative effectiveness research: the PCORI perspective. JAMA 2012;307(15):1636-40. [PUBMED: 22511692]

\section{Aslan 2007}

Aslan M, Freeman BA. Redox-dependent impairment of vascular function in sickle cell disease. Free Radical Biology \& Medicine 2007;43:1469-83. [PUBMED: 17964418]

\section{Asnani 2009}

Asnani MR, Lipps GE, Reid ME. Utility of WHOQOL-BREF in measuring quality of life in sickle cell disease. Health and Quality of Life Outcomes 2009;7:75. [PUBMED: 19664266]

\section{Ballas 2002}

Ballas SK. Treatment of painful sickle cell leg ulcers with topical opioids. Blood 2002;99:1096. [PUBMED: 11822360]

\section{Ballas 2010}

Ballas SK, Lieff S, Benjamin LJ, Dampier CD, Heeney MM, Hoppe C, et al. Definitions of the phenotypic manifestations of sickle cell disease. American Journal of Hematology 2010;85(1):6-13. [PUBMED: 19902523]

\section{Balshem 2011}

Balshem H, Helfand M, Schunemann HJ, Oxman AD, Kunz R, Brozek J, et al. GRADE guidelines: 3 . Rating the quality of evidence. Journal of Clinical Epidemiology 2011;64(4):401-6. [PUBMED: 21208779]

\section{Bardakdjian-Michau 2009}

Bardakdjian-Michau J, Bahuau M, Hurtrel D, Godart C, Riou J, Mathis $\mathrm{M}$, et al. Neonatal screening for sickle cell disease in France. Journal of Clinical Pathology 2009;62:31-3. [PUBMED: 19103855]

\section{Bender 2009}

Bender DA. A dictionary of food and nutrition. 3rd Edition. New York: Oxford University Press, 2009. [978-0-19-923487-5]

\section{Bergin 2006}

Bergin SM, Wraight P. Silver based wound dressings and topical agents for treating diabetic foot ulcers. Cochrane Database of Systematic Reviews 2006, Issue 1. [DOI: 10.1002/14651858.CD005082.pub2]

\section{Cacciola 1989}

Cacciola E, Giustolisi R, Musso R, Longo A, Cacciola E. Antithrombin III concentrate for treatment of chronic leg ulcers in sickle cell-beta thalassemia: a pilot study. Annals of Internal Medicine 1989;111:534-6. [PUBMED: 2774375]

\section{Cacciola 1990a}

Cacciola E, Musso R, Giustolisi R, Cacciola E, Alessi M. Blood hypercoagulability as a risk factor for leg ulcers in sickle cell disease. Blood 1990;75(12):2467-8. [PUBMED: 2350585]

\section{Chalchal 2001}

Chalchal H, Rodino W, Hussain S, Haq I, Panetta T, Solomon W, Gillette $P$, et al. Impaired venous hemodynamics in a minority of patients with chronic leg ulcers due to sickle cell anemia. VASA. Zeitschrift für Gefässkrankheiten. Journal for Vascular Diseases 2001;30:277-9. [PUBMED: 11771212]

\section{Clare 2002}

Clare A, FitzHenley M, Harris J, Hambleton I, Serjeant GR. Chronic leg ulceration in homozygous sickle cell disease: the role of venous incompetence. British Journal of Haematology 2002;119:567-71. [PUBMED: 12406102] 


\section{Clarke 2007}

Clarke M. Standardising outcomes for clinical trials and systematic reviews. Trials 2007;8:39. [PUBMED: 18039365]

\section{Creary 2007}

Creary M, Williamson D, Kulkarni R. Sickle cell disease: current activities, public health implications, and future directions. Journal of Women's Health 2007;16:575-82. [PUBMED: 17627395]

\section{Cumming 2008}

Cumming V, King L, Fraser R, Serjeant G, Reid M. Venous incompetence, poverty and lactate dehydrogenase in Jamaica are important predictors of leg ulceration in sickle cell anaemia. British Journal of Haematology 2008;142:119-25. [PUBMED: 18477043]

\section{Daudt 2007}

Daudt LE, Zechmaister D, Portal L, Neto EC, Silla LM, Giugliani R. Neonatal screening for hemoglobinopathies: a pilot study in Porto Alegre, Rio Grande do Sul, Brazil [Triagem neonatal para hemoglobinopatias: um estudo piloto em Porto Alegre, Rio Grande do Sul, Brasil]. Cadernos de Saúde Pública 2002;18:833-41. [PUBMED: 12048609]

\section{Durosinmi 1991}

Durosinmi MA, Gevao SM, Esan GJ. Chronic leg ulcers in sickle cell disease: experience in Ibadan, Nigeria. African Journal of Medicine and Medical Sciencies 1991;20:11-4. [PUBMED: 1905464]

\section{Eckman 1996}

Eckman JR. Leg ulcers in sickle cell disease. Hematology/ Oncology Clinics of North America 1996;10:1333-44. [PUBMED: 8956020]

\section{Edwards 2002}

Edwards J. Debridement of diabetic foot ulcers. Cochrane Database of Systematic Reviews 2002, Issue 4. [DOI: 10.1002/14651858.CD003556.pub2]

\section{Espinosa 1992}

Espinosa Martínez E, Villarreal Piloto C, Torres A, González A. Hyperbaric oxygen in the treatment of malleolar ulcer from sickle cell anemia [Oxigeno hiperbárico en el tratamiento de la úlcera maleolar de la anemia drepanocitica]. Revista Cubana de Hematología, Inmunología y Hemoterapia 1992;8:28-36. [112188]

\section{Frost 1990}

Frost ML, Treadwell P. Treatment of sickle cell leg ulcers with pentoxifylline. International Journal of Dermatology 1990;29:375-6. [PUBMED: 2361798]

\section{Gabriel 2012}

Gabriel SE, Normand SL. Getting the Methods Right - The Foundation of Patient-Centered Outcomes Research. The New England Journal of Medicine 2012; Vol. Jul 25:Epub ahead of print. [PUBMED: 22830434]

\section{Gordon 2003}

Gordon S, Bui A. Human skin equivalent in the treatment of chronic leg ulcers in sickle cell disease patients. Journal of the American Podiatry Association 2003;93:240-1. [PUBMED: 12756317]

\section{GRADEPro 2014 [Computer program]}

www.gradepro.org. GRADEpro. Version 20th October 2014. McMaster University, 2014.

\section{Gulbis 2006}

Gulbis B, Ferster A, Cotton F, Lebouchard MP, Cochaux P, Vertongen $F$. Neonatal haemoglobinopathy screening: review of a 10-year programme in Brussels. Journal of Medical Screening 2006;13:76-8. [PUBMED: 16792829]

\section{Guyatt 2011}

Guyatt GH, Oxman AD, Kunz R, Brozek J, Alonso-Coello P, Rind $D$, et al. GRADE guidelines 6 . Rating the quality of evidence--imprecision. Journal of Clinical Epidemiology 2011;64(12):1283-93. [PUBMED: 21839614]

\section{Guyatt 2011a}

Guyatt GH, Oxman AD, Kunz R, Woodcock J, Brozek J, Helfand M, et al. GRADE guidelines: 7. Rating the quality of evidence--inconsistency. Journal of Clinical Epidemiology 2011;64(12):1294-302. [PUBMED: 21803546]

\section{Guyatt 2011b}

Guyatt GH, Oxman AD, Montori V, Vist G, Kunz R, Brozek J, et al. GRADE guidelines: 5 . Rating the quality of evidence--publication bias. Journal of Clinical Epidemiology 2011;64(12):1277-82. [PUBMED: 21802904]

\section{Guyatt 2011c}

Guyatt GH, Oxman AD, Kunz R, Woodcock J, Brozek J, Helfand M, et al. GRADE guidelines: 8 . Rating the quality of evidence--indirectness. Journal of Clinical Epidemiology 2011;64(12):1303-10. [PUBMED: 21802903]

\section{Guyatt 2011d}

Guyatt GH, Oxman AD, Sultan S, Glasziou P, Akl EA, AlonsoCoello P, et al. GRADE guidelines: 9. Rating up the quality of evidence. Journal of Clinical Epidemiology 2011;64(12):1311-6. [PUBMED: 21802902]

\section{Guyatt 2011e}

Guyatt GH, Oxman AD, Vist G, Kunz R, Brozek J, Alonso-Coello P, et al. GRADE guidelines: 4. Rating the quality of evidence-study limitations (risk of bias). Journal of Clinical Epidemiology 2011;64(4):407-15. [PUBMED: 21247734]

\section{Guyatt $2011 f$}

Guyatt G, Oxman AD, Akl EA, Kunz R, Vist G, Brozek J, et al. GRADE guidelines: 1. Introduction-GRADE evidence profiles and summary of findings tables. Journal of Clinical Epidemiology 2011;64(4):383-94. [PUBMED: 21195583]

\section{Guyatt 2011g}

Guyatt GH, Oxman AD, Kunz R, Atkins D, Brozek J, Vist G, et al. GRADE guidelines: 2 . Framing the question and deciding 
on important outcomes. Journal of Clinical Epidemiology 2011;64(4):395-400. [PUBMED: 21194891]

\section{Guyatt 2011h}

Guyatt GH, Oxman AD, Schunemann HJ, Tugwell P, Knottnerus A. GRADE guidelines: a new series of articles in the Journal of Clinical Epidemiology. Journal of Clinical Epidemiology 2011;64(4):380-2. [PUBMED: 21185693]

\section{Guyatt 2012}

Guyatt G, Oxman AD, Sultan S, Brozek J, Glasziou P, AlonsoCoello $P$, et al. GRADE guidelines 11-making an overall rating of confidence in effect estimates for a single outcome and for all outcomes. Journal of Clinical Epidemiology 2012;Apr 27:Epub print. [PUBMED: 22542023]

\section{Hagar 2008}

Hagar W, Vichinsky E. Advances in clinical research in sickle cell disease. British Journal of Haematology 2008;141:346-56. [PUBMED: 18341629]

\section{Halabi -Tawil 2008}

Halabi-Tawil M, Lionnet F, Girot R, Bachmeyer C, Levy PP, Aractingi S. Sickle cell leg ulcers: a frequently disabling complication and a marker of severity. British Journal of Dermatology 2008;158:339-44. [PUBMED: 18047512]

\section{Harrel 1990}

Harrell HL Jr. L-carnitine for leg ulcers. Annals of Internal Medicine 1990;113:412. [PUBMED: 2382928]

\section{Henthorn 2004}

Henthorn JS, Almeida AM, Davies SC. Neonatal screening for sickle cell disorders. British Journal of Haematology 2004;124:259-63. [PUBMED: 14717772]

\section{Higgins 2003}

Higgins JP, Thompson SG, Deeks JJ, Altman DG. Measuring inconsistency in meta-analyses. BMJ 2003;327(7414):557-60. [PUBMED: 12958120]

\section{Higgins 2011}

Higgins JPT, Green S (editors). Cochrane Handbook for Systematic Reviews of Interventions. The Cochrane Collaboration. Available from www.cochrane-handbook.org 2011; Vol. Version 5.1.0 [updated March 2011].

\section{Higgins 2011a}

Higgins JPT, Altman DG (editors). Chapter 8: Assessing risk of bias in included studies. Cochrane Handbook for Systematic Reviews of Interventions Version 5.1.0 (updated March 2011). The Cochrane Collaboration, 2011. Available from www.cochrane-handbook.org.

\section{Higgins 2011b}

Higgins JPT, Deeks JJ, Altman DG on behalf of the CSMG. Chapter 16: Special topics in statistics. In: Higgins JPT, Green $S$ (editors). Cochrane Handbook of Systematic Reviews of Interventions. Version 5.1 [updated March 2011]. The Cochrane Collaboration, 2011. Available from www.cochranehandbook.org.

\section{Hopewell 2010}

Hopewell S, Clarke M, Higgins JPT (editors). Core reporting of outcomes in effectiveness trials. Cochrane Methods. Cochrane DB Syst Rev 2010; Vol. Suppl 1:1-29. [ISSN 2044-4702]

\section{loannidis 2004}

Ioannidis JP, Evans SJ, Gotzsche PC, O'Neill RT, Altman DG, Schulz K, et al. Better reporting of harms in randomized trials: an extension of the CONSORT statement. Annals of Internal Medicine 2004;141(10):781-8. [PUBMED: 15545678]

\section{loannidis 2010}

loannidis JP. Meta-research: The art of getting it wrong. Research Synthesis Methods 2010;1(3-4):169-84.

\section{Kato 2007}

Kato GJ, Gladwin MT, Steinberg MH. Deconstructing sickle cell disease: reappraisal of the role of hemolysis in the development of clinical subphenotypes. Blood Reviews 2007;21:37-47. [PUBMED: 17084951]

\section{Kato 2009}

Kato GJ, Hebbel RP, Steinberg MH, Gladwin MT. Vasculopathy in sickle cell disease: Biology, pathophysiology, genetics, translational medicine, and new research directions. American Journal of Hematology 2009;84:618-25. [PUBMED: 19610078]

\section{Kirkham 2010}

Kirkham JJ, Dwan KM, Altman DG, Gamble C, Dodd S, Smyth R, et al. The impact of outcome reporting bias in randomised controlled trials on a cohort of systematic reviews. BMJ 2010;340:c365. [PUBMED: 20156912]

\section{Knox-Macaulay 1983}

Knox-Macaulay HH. Sickle cell disease in Sierra Leone: a clinical and haematological analysis in older children and adults. Annals of Tropical Medicine and Parasitology 1983;77:411-9. [PUBMED: 6639186]

\section{Koshy 1989}

Koshy M, Entsuah R, Koranda A, Kraus AP, Johnson R, Bellvue R, et al. Leg ulcers in patients with sickle cell disease. Blood 1989;74:1403-8. [PUBMED: 2475188]

\section{La Grenade 2003}

La Grenade L, Thomas PW, Serjeant GR. A randomized controlled trial of solcoseryl and duoderm in chronic sickle-cell ulcers. West Indian Medical Journal 1993;42:121-3. [PUBMED: 8273321]

\section{Lionnet 2008}

Lionnet F, Bachmeyer C, Stankovic K, Tharaux PL, Girot R, Aractingi S. Efficacy of the endothelin receptor blocker bosentan for refractory sickle cell leg ulcers. British Journal of Haematology 2008;142:991-2. [PUBMED: 18671710]

\section{MacFarlane 1986}

MacFarlane DE, Baum KF, Serjeant GR. Bacteriology of sickle cell leg ulcers. Transactions of the Royal Society of Tropical Medicine and Hygiene 1986;80:553-6. [PUBMED: 3101240] 


\section{Mack 2006}

Mack AK, Kato GJ. Sickle cell disease and nitric oxide: a paradigm shift?. The International Journal of Biochemistry \& Cell Biology 2006;38:1237-43. [PUBMED: 16517208 ]

\section{Makani 2007}

Makani J, Williams TN, Marsh K. Sickle cell disease in Africa: burden and research priorities. Annals of Tropical Medicine and Parasitology 2007;101:3-14. [MEDLINE: 17244405]

\section{Martin 2011}

Martin E. Concise Medical Dictionary. 8th Edition. New York: Oxford University Press, 2011.

\section{Mañú 2009}

Mañú Pereira M, Corrons JL. Neonatal haemoglobinopathy screening in Spain. Journal of Clinical Pathology 2009;62:22-5. [PUBMED: 19103853]

\section{Mery 2004}

Mery L, Girot R, Aractingi S. Topical effectiveness of molgramostim (GM-CSF) in sickle cell leg ulcers. Dermatology 2004;208:135-7. [PUBMED: 15057003]

\section{Minniti 2010}

Minniti CP, Eckman J, Sebastiani P, Steinberg MH, Ballas SK. Leg ulcers in sickle cell disease. American Journal of Hematology 2010;85(10):831-3. [MEDLINE: 20872960]

\section{Modell 2008}

Modell B, Darlison M. Global epidemiology of haemoglobin disorders and derived service indicators. Bulletin of the World Health Organization 2008;86:480-7. [PUBMED: 18568278]

\section{Mohan 1997}

Mohan JS, Marshall JM, Reid HL, Thomas PW, Serjeant GR. Postural vasoconstriction and leg ulceration in homozygous sickle cell disease. Clinical Science 1997;92:153-8. [PUBMED: 9059316]

\section{Mohan 2000}

Mohan JS, Vigilance JE, Marshall JM, Hambleton IR, Reid HL, Serjeant GR. Abnormal venous function in patients with homozygous sickle cell (SS) disease and chronic leg ulcers. Clinical Science 2000;98:667-72. [PUBMED: 10814603]

\section{Moher 2010}

Moher D, Hopewell S, Schulz KF, Montori V, Gøtzsche PC, Devereaux PJ, et al. CONSORT 2010 explanation and elaboration: updated guidelines for reporting parallel group randomised trials. BMJ 2010;340:c869. [MEDLINE: 20332511]

\section{Moore 2005}

Moore ZEH, Cowman S. Wound cleansing for pressure ulcers. Cochrane Database of Systematic Reviews 2005, Issue 4. [DOI: 10.1002/14651858.CD004983.pub2]

\section{Morgan 1981}

Morgan AG, Venner AM. Immunity and leg ulcers in homozygous sickle cell disease. Journal of Clinical \& Laboratory Immunology 1981;6:51-5. [PUBMED: 7265175]

\section{Morris 2008}

Morris CR. Mechanisms of vasculopathy in sickle cell disease and thalassemia. Hematology / the Education Program of the American Society of Hematology. American Society of Hematology. Education Program 2008; Vol. 2008, issue 1:177-85. [PUBMED: 19074078]

\section{Mousa 2010}

Mousa SA, Qari MH. Diagnosis and management of sickle cell disorders. Methods in Molecular Biology 2010;663:291-307. [PUBMED: 20617425]

\section{Nebeker 2004}

Nebeker JR, Barach P, Samore MH. Clarifying adverse drug events: a clinician's guide to terminology, documentation, and reporting. Annals of Internal Medicine 2004;140(10):795-801. [PUBMED: 15148066]

\section{Nelson 2000}

Nelson EA, Bell-Syer SEM, Cullum NA. Compression for preventing recurrence of venous ulcers. Cochrane Database of Systematic Reviews 2000, Issue 4. [DOI: 10.1002/14651858.CD002303]

\section{Nolan 2006}

Nolan VG, Baldwin C, Wang L, Ma Q, Wyszynski DF, Farrell JJ, Sebastiani P, et al. Sickle Cell Leg Ulcers: Associations with Haemolysis and SNPs in Klotho, TEK and Genes of the TGF-beta/BMP Pathway. British Journal of Haematology 2006;133(5):570-8. [PUBMED: 16681647]

\section{O'Meara 2000}

O'Meara S, Cullum N, Majid M, Sheldon T. Systematic reviews of wound care management: (3) antimicrobial agents for chronic wounds; (4) diabetic foot ulceration. Health Technology Assessment 2000;4(21):1-237. [PUBMED: 11074391]

\section{O'Meara 2009}

O'Meara S, Cullum NA, Nelson EA. Compression for venous leg ulcers. Cochrane Database of Systematic Reviews 2009, Issue 1. [DOI: 10.1002/14651858.CD000265.pub2]

\section{O'Meara 2010}

O'Meara S, Al-Kurdi D, Ovington LG. Antibiotics and antiseptics for venous leg ulcers. Cochrane Database of Systematic Reviews 2010, Issue 1. [DOI: 10.1002/14651858.CD003557.pub3]

\section{Ofosu 1987}

Ofosu MD, Castro O, Alarif L. Sickle cell leg ulcers are associated with HLA-B35 and Cw4. Archives of Dermatology 1987;123(4):482-4. [PUBMED: 3493733]

\section{Orkin 2010}

Orkin SH, Higgs DR. Medicine. Sickle cell disease at 100 years. Science (New York, N.Y.) 2010;329(5989):291-2. [PUBMED: 20647458]

\section{Paladino 2007}

Paladino SF. Leg ulcers in sickle cell disease. Revista Brasileira de Hematologia e Hemoterapia 2007;29:288-90. [470902] 


\section{Palfreyman 2006}

Palfreyman SSJ, Nelson EA, Lochiel R, Michaels JA. Dressings for healing venous leg ulcers. Cochrane Database of Systematic Reviews 2006, Issue 3. [DOI: 10.1002/14651858.CD001103.pub2]

\section{Pieters 1995}

Pieters RC, Rojer RA, Saleh AW, Saleh AE, Duits AJ.

Molgramostim to treat SS-sickle cell leg ulcers. Lancet 1995;345:528. [PUBMED: 7861910]

\section{Porta 2008}

Porta M (ed). Dictionary of Epidemiology. 5th Edition. New York: Oford University Press, 2008. [ISBN 978-0-19-531449-6]

\section{Prabhakar 2010}

Prabhakar H, Haywood C Jr, Molokie R. Sickle cell disease in the United States: looking back and forward at 100 years of progress in management and survival. American Journal of Hematology 2010;85(5):346-53. [PUBMED: 20425797]

\section{Ramalho 1985}

Ramalho AS, Velloso LA, Diniz M. Sickle cell syndromes and ulcer of inferior extremities [Síndromes falcêmicas e úlceras de membros inferiores]. Anais Brasileiros de Dermatologia 1985;60:307-10. [29971]

\section{Rees 2010}

Rees DC, Williams TN, Gladwin MT. Sickle-cell disease. Lancet 2010;376(9757):2018-31. [PUBMED: 21131035]

\section{Reindorf 1989}

Reindorf CA, Walker-Jones D, Adekile AD, Lawal O, Oluwole SF. Rapid healing of sickle cell leg ulcers treated with collagen dressing. Journal of the National Medical Association 1989;81:866-8. [PUBMED: 2769790]

\section{Rice 1953}

Rice SM. Healing of chronic sicklemia leg ulcers healed by cortisone. A.M.A. Archives of Dermatology and Syphilology 1953;68:576-9. [PUBMED: 13091419]

\section{Santen 2004}

Santen SA. Transfusion therapy. In: Tintinalli JE, Kellen GD, Stapczynski JS editor(s). Emergency Medicine: A comprehensive study guide. 6th Edition. New York: McGraw Hill, 2004:1348-53. [0-07138875-3]

\section{Schleucher 2007}

Schleucher R, Gaessler M, Knobloch J. Rapid healing of a late diagnosed sickle cell leg ulcer using a new combination of treatment methods. Journal of Wound Care 2007;16(5):197-8. [PUBMED: 17552401]

\section{Sehgal 1992}

Sehgal SC, Arunkumar BK. Microbial flora and its significance in pathology of sickle cell disease leg ulcers. Infection 1992;20(2):86-8. [PUBMED: 1582689] with leg ulceration. Clinical and Experimental Hypertension 2009;31(1):44-8. [PUBMED: 19172458]

\section{Serjeant 2005}

Serjeant GR, Serjeant BE, Mohan JS, Clare A. Leg ulceration in sickle cell disease: medieval medicine in a modern world. Hematology/Oncology Clinics of North America 2005;19(5):943-56. [PUBMED: 16214654]

\section{Serjeant 2010}

Serjeant GR. One hundred years of sickle cell disease. British Journal of Haematology 2010;151(5):425-9. [PUBMED: 20955412]

\section{Sher 1994}

Sher GD, Olivieri NF. Rapid healing of chronic leg ulcers during arginine butyrate therapy in patients with sickle cell disease and thalassemia. Blood 1994;84(7):2378-80. [PUBMED: 7919358]

\section{Smith 2011}

Smith F, Dryburgh N, Donaldson J, Mitchell M. Debridement for surgical wounds. Cochrane Database of Systematic Reviews 2011, Issue 5. [DOI: 10.1002/14651858.CD006214.pub3]

\section{Spence 1985}

Spence RJ. The use of a free flap in homozygous sickle cell disease. Plastic and Reconstructive Surgery 1985;76(4):616-9. [MEDLINE: 4034781]

\section{Steinberg 2009}

Steinberg MH. Genetic etiologies for phenotypic diversity in sickle cell anemia. Scientific World Journal 2009;9:46-67. [PUBMED: 19151898]

\section{Taylor 2008}

Taylor JG 6th, Nolan VG, Mendelsohn L, Kato GJ, Gladwing MT, Steinberg MH. Chronic hyper-hemolysis in sickle cell anemia: association of vascular complications and mortality with less frequent vasooclussive pain. PloSOne 2008;3:e2095. [PUBMED: 18461136]

\section{Trent 2004}

Trent JT, Kirsner RS. Leg ulcers in sickle cell disease. Advances in Skin \& Wound Care 2004;17(8):410-6. [PUBMED: 15492676]

\section{Tshilolo 2008}

Tshilolo L, Kafando E, Sawadogo M, Cotton F, Vertongen F, Ferster A, et al. Neonatal screening and clinical care programmes for sickle cell disorders in sub-Saharan Africa: lessons from pilot studies. Public Health 2008;122(9):933-41. [PUBMED: 18555498]

\section{Vermeulen 2004}

Vermeulen H, Ubbink DT, Goossens A, de Vos R, Legemate DA. Dressings and topical agents for surgical wounds healing by secondary intention. Cochrane Database of Systematic Reviews 2004, Issue 1. [DOI: 10.1002/14651858.CD003554.pub2]

\section{Serarslan 2009}

Serarslan G, Akgül F, Babayigit C. High prevalence of pulmonary hypertension in homozygous sickle cell patients 


\section{Wasiak 2008}

Wasiak J, Cleland H, Campbell F. Dressings for superficial and partial thickness burns. Cochrane Database of Systematic Reviews 2008, Issue 4. [DOI: 10.1002/14651858.CD002106.pub3]

\section{Weatherall 2006}

Weatherall D, Akinyanju O, Fucharoen S, Olivieri N, Musgrove P. Inherited Disorders of Hemoglobin. Disease Control Priorities in Developing Countries. 2nd Edition. Washington DC: The World Bank and Oxford University Press, 2006.

\section{Wilkinson 1998}

Wilkinson EAJ, Hawke CC. Oral zinc for arterial and venous leg ulcers. Cochrane Database of Systematic Reviews 1998, Issue 4. [DOI: 10.1002/14651858.CD001273]

\section{CHARACTERISTICS OF STUDIES}

Characteristics of included studies [ordered by study ID]

\section{Wood 2008}

Wood KC, Hsu LL, Gladwin MT. Sickle cell disease vasculopathy: a state of nitric oxide resistance. Free Radical Biology and Medicine 2008;44(8):1506-28. [PUBMED: 18261470]

\section{References to other published versions of this review Martí-Carvajal 2012}

Martí-Carvajal AJ, Knight-Madden JM, Martinez-Zapata MJ. Interventions for treating leg ulcers in people with sickle cell disease. Cochrane Database of Systematic Reviews 2012, Issue 11. [DOI: 10.1002/14651858.CD008394.pub2]

* Indicates the major publication for the study

\section{Baum 1987}

Methods Desing trial: parallel (2 groups).

Study phase: not described.

Baseline observation period: no (Dr Graham Serjeant, interviewed by one author of this review (JKM), on February 4, 2011).

Follow-up period: 8 weeks.

Randomisation unit: patient.

Unit of analysis: ulcers.

Intention to treat: unclear.

Participants

Total: 30 .

Antibiotic therapy: 16.

Placebo: 14

Withdrawals: $7 \%$ (2/30) (1 from each group).

Reported leg ulcers at the start of the trial: 40 (data supplied by Dr Graham Serjeant, Jamaica, February 4, 2011).

Age: median (range). Antibiotic therapy group: 29 years (14 - 44 years); control group: 25 years (17 - 49 years).

Number of ulcers: 40 (antibiotic therapy: 20; placebo: 20).

Duration (median):

Antibiotic therapy group: 3.6 years (range: 0.3 to 15 years).

Control group: 3.5 years (range: 0.3 to 12 years).

Mean baseline ulcer area $\left(\mathrm{cm}^{2}\right) \pm$ SD. Antibiotic therapy group: 20.0 (14.9); placebo: 20.8 (19.0).

Gender (male:female). Antibiotic therapy group: 4:9; control: 6:9.

Inclusion criteria:

1. Hb SS;

2. leg ulceration of at least 3 months duration;

3. bacterial swabs revealed at least one of the skin pathogen;

4. to attend at 2-weekly intervals;

5. to agree to the trial protocol;

6. multiple ulcers: yes, all used (data supplied by Dr Graham Serjeant, Jamaica, February 4, 2011).

7. new ulcers discussed: not information (Data supplied by Dr Graham Serjeant, Jamaica, February 4, 2011). 
Baum 1987 (Continued)

Exclusion criteria:

1. large leg ulcers;

2. chronic renal failure.

\begin{tabular}{|c|c|}
\hline \multirow[t]{6}{*}{ Interventions } & $\begin{array}{l}\text { Antimicrobial therapy (aerosol preparation, twice daily): } \\
\text { neomycin, bacitracin and polymyxin B. }\end{array}$ \\
\hline & Control (aerosol dispenser, twice daily). \\
\hline & Placebo: sterile normal saline with 1:1000 red food colouring. \\
\hline & Co-intervention: disinfectant (Eusol). \\
\hline & Rest with elevation of the affected leg(s). \\
\hline & Systematic antibiotics: not allowed. \\
\hline & \\
\hline \multirow[t]{3}{*}{ Outcomes } & Primary: pain. \\
\hline & $\begin{array}{l}\text { Likely secondary outcomes (these end points were not described at 'methods section'): healing rate; } \\
\text { bacteriological investigation. }\end{array}$ \\
\hline & $\begin{array}{l}\text { According with Dr Graham Serjeant, interviewed by one author of this review (JKM), 'ulcer area-change' } \\
\text { was the primary outcome (February 4, 2011). }\end{array}$ \\
\hline \multirow[t]{6}{*}{ Notes } & 1. This trial was described as "randomised controlled crossover trial" at Proceedings of the Com- \\
\hline & $\begin{array}{l}\text { monwealth Caribean medical Research Council (31st Scientific Meeting, 1986, April 16-19, Port Spain, } \\
\text { Trinidad and Tobago. }\end{array}$ \\
\hline & 2. Country: University Hospital of the West Indies, Kingston, Jamaica. \\
\hline & 3. Study time: 10 June to 9 September 1993. \\
\hline & 4. Sample size estimation a priori: not stated. \\
\hline & $\begin{array}{l}\text { 5. } 3 \mathrm{M} \text { Company Incorporated donated Rikospray }{ }^{\oplus} \text {, an aerosol preparation of neomycin, bacitracin, and } \\
\text { polymyxin B. }\end{array}$ \\
\hline
\end{tabular}

\section{Risk of bias}

Bias Authors' judgement Support for judgement

Random sequence genera- Unclear risk tion (selection bias)
Quote: "patients were assigned, using size 4 block randomization" (page 847). Comments: there is an imbalance in two characteristics baseline: zinc therapy was only received by control patients and marked pain ( 14 placebo patients vs 8 patients treatment).

Insufficient information about the sequence generation process to permit judgement of 'low risk' or 'high risk'.

Allocation concealment $\quad$ Unclear risk Insufficient information to permit judgement of 'low risk' or 'high risk'.
(selection bias)

Blinding of participants Unclear risk Insufficient information to permit judgement of 'low risk' or 'high risk'
and personnel (perfor-
mance bias)
All outcomes

\begin{tabular}{lll}
\hline $\begin{array}{l}\text { Blinding of outcome as- } \\
\text { sessment (detection bias) } \\
\text { All outcomes }\end{array}$ & Unclear risk & Insufficient information to permit judgement of 'low risk' or 'high risk'. \\
\hline $\begin{array}{l}\text { Incomplete outcome data } \\
\text { (attrition bias) }\end{array}$ & Unclear risk & $\begin{array}{l}\text { Insufficient reporting of attrition and exclusions to permit judgement of 'low } \\
\text { risk' or 'high risk'. }\end{array}$ \\
\hline
\end{tabular}


Baum 1987 (Continued)

Selective reporting ( $r$ porting bias)

High risk

One or more clinically relevant and reasonably expected outcomes were not reported on; data on these outcomes were likely to have been recorded (i.e. safety).

According with Dr Graham Serjeant, interviewed by one author of this review (JKM), 'ulcer area-change' was the primary outcome (February 4, 2011).

Other bias

High risk
Ascertaiment bias and bias in the presentation of data (Appendix 2).

Table of characteristics of patients at entry study only shows 28 patients.

There is inconsistency relating to the study design and the healing rate end point.

The inconsistency between 'Randomisation unit: patient' and 'Unit of analysis: ulcers' could generate the design and confusion bias (Appendix 2).

\section{La Grenade 1993}

$\begin{array}{ll}\text { Methods } & \text { Desing trial: parallel (3 groups). } \\ & \text { Study phase: not described. } \\ & \text { Baseline observation period: } 3 \text { months. } \\ & \text { Follow-up period: } 12 \text { weeks. } \\ & \text { Randomisation unit: ulcers. } \\ & \text { Unit of analysis: ulcers. } \\ \text { Intention to treat: unclear. }\end{array}$

\section{Participants}

Sample size: 32 participants.

Randomised leg ulcers: 49 (Solcoseryl ${ }^{\circledR} 14$; hydrocolloid dressing 14; placebo 21).

Loss patients reported: 14 (Solcoseryl ${ }^{\oplus} 4$; hydrocolloid dressing: 8; placebo: 2 ).

(Dr. Graham Serjeant, interviewed by one author of this review (JKM), on February 4, 2011).

16 (Solcoseryl ${ }^{\circledR}:$ 3); hydrocolloid dressing: 8); (Placebo: 5)

Loss (\%): 50\%.

Age: Mean ( \pm SD): Solcoseryl $l^{\oplus}: 27.0$ years (8.2); hydrocolloid dressing: 35.5 years (9.8); placebo: $30.7(8.2)$.

Gender (males): Solcoseryl : 93\%; hydrocolloid dressing: 50\%; placebo: $71 \%$.

Inclusion criteria:

1. Patients with $\mathrm{Hb} \mathrm{SS}$.

2. Age (years): $\geq 15$

3. Leg ulcer duration: $\geq 16$ months.

4. Ulcer size: $\geq 3 \mathrm{~cm}$.

5. Patients attending for a 3-month baseline observation period.

Exclusion criteria: not described.

1. Solcoseryl ${ }^{\oplus}$ (de-proteinized extract of calf blood) supplied in tubes as jelly or ointment, twice daily after cleaning with Eusol, covered with a gauze dressing and supported by an Elastoweb bandage.

2. Hydrocolloid dressing (hydroactive dressing) supplied as sheets of occlusive dressing and as granules. and covered with gauze and supported by an Elastoweb bandage. The dressing was replaced at weekly intervals or more often if indicated.

Control: Twice-daily cleaning with a mild antiseptic agent (Eusol), wet dressing and a firm supportive elastic bandage.

$\begin{array}{ll}\text { Outcomes } & \text { Healing ulcer. } \\ \text { According with Dr Graham Serjeant, interviewed by one author of this review (JKM), 'ulcer area- } \\ \text { change' was the primary outcome (February 4, 2011). }\end{array}$


La Grenade 1993 (Continued)

Notes
Centre and Country: Sickle-cell Clinic of the University Hospital of the West Indies, Kingston, Jamaica.

Solcoseryl $\mathrm{l}^{\oplus}$ was supplied by Solco Basle Ltd.

Hydrocolloid dressing by Convatec.

Sample size estimation a priori: no described.

\section{Risk of bias}

Bias Authors' judgement Support for judgement

Random sequence genera- Unclear risk tion (selection bias)

Quote: "Unilateral ulcers were randomized into one of three treatment schedules in blocks of three" and "In bilateral ulcers, one leg was randomized to one of the two treatment agents and the other leg to control therapy" (page 121).

Insufficient information about the sequence generation process to permit judgement of 'low risk' or 'high risk'.

Allocation concealment $\quad$ Unclear risk Insufficient information to permit judgement of 'low risk' or 'high risk'.
(selection bias)

\begin{tabular}{|c|c|c|}
\hline $\begin{array}{l}\text { Blinding of participants } \\
\text { and personnel (perfor- } \\
\text { mance bias) } \\
\text { All outcomes }\end{array}$ & Unclear risk & Insufficient information to permit judgement of 'low risk' or 'high risk' \\
\hline $\begin{array}{l}\text { Blinding of outcome as- } \\
\text { sessment (detection bias) } \\
\text { All outcomes }\end{array}$ & Unclear risk & Insufficient information to permit judgement of 'low risk' or 'high risk' \\
\hline $\begin{array}{l}\text { Incomplete outcome data } \\
\text { (attrition bias) } \\
\text { All outcomes }\end{array}$ & High risk & $\begin{array}{l}\text { Dropouts: } 50 \%(16 / 32) \text { (Placebo } 24 \%(5 / 21) \text {; Solcoseryl }\left.\right|^{\oplus} 21.4 \%(3 / 14) \text {; hydro- } \\
\text { colloid dressing } 57.1 \%(8 / 14) \text {. } \\
\text { Reasons: none described. } \\
\text { Imbalance between hydrocolloid dressing group and the other groups }>10 \% \text {. }\end{array}$ \\
\hline $\begin{array}{l}\text { Selective reporting (re- } \\
\text { porting bias) }\end{array}$ & High risk & $\begin{array}{l}1 \text { or more clinically relevant and reasonably expected outcomes were not re- } \\
\text { ported on; data on these outcomes were likely to have been recorded (i.e. } \\
\text { safety). }\end{array}$ \\
\hline Other bias & High risk & $\begin{array}{l}\text { Ascertaiment and design bias and bias in the presentation of data (Appendix } \\
\text { 2). }\end{array}$ \\
\hline
\end{tabular}

\section{McMahon 2010}

\begin{tabular}{ll}
\hline Methods & Design trial: parallel (2 groups). \\
& Study phase: Il. \\
& Follow-up period: 12 weeks. \\
& Randomisation unit: patients. \\
& Unit of analysis: ulcers \\
Intention-to-treat: unclear.
\end{tabular}


Mean baseline ulcer area $\left(\mathrm{cm}^{2}\right) \pm \mathrm{SE}$ : arginine butyrate plus standard local care: $25.7 \mathrm{~cm}^{2}(8.1)$; standard local care: $50.6 \mathrm{~cm}^{2}$ (13.9).

Total number ulcers: arginine butyrate plus standard local care: 37 ; standard local care: 25.

Number of ulcers per patient: arginine butyrate plus standard local care: 3.5 ; standard local care: 2.1 .

Inclusion criteria:

1. Age: $>18$ years.

2. Sickle cell anaemia or sickle beta thalassaemia.

3. Presence of one or more leg ulcers which had been refractory to healing with National Institutes of Health (NIH)-defined standard local care, consisting of twice-daily cleaning and wet-to-dry dressing changes, for at least 6 months.

4.Patients were also eligible to participate if an ulcer had recurred and not healed with at least 3 months of standard care.

Exclusion criteria:

1. Renal or hepatic compromise.

2. Current chronic transfusion therapy.

Interventions

Intervention*: arginine butyrate at a total daily dose of $500 \mathrm{mg} / \mathrm{kg} / \mathrm{dose}$ given $5 \mathrm{~d} /$ week plus standard local care.

Arginine butyrate formulation: $5 \%$ butyric acid $(50 \mathrm{~g} / \mathrm{l})$ and $7.5 \% \mathrm{~L}$-arginine $(75 \mathrm{~g} / \mathrm{l})$ by intravenous infusion through a port-a-cath or peripheral pass-port, generally over $6-8 \mathrm{~h} / \mathrm{d}$.

The administration rate: $85 \mathrm{mg} / \mathrm{kg} / \mathrm{h}$ and those patients infused with rates $>60 \mathrm{mg} / \mathrm{kg} / \mathrm{h}$ were premedicated with acetaminophen or ibuprofen and an anti-emetic to prevent headache or nausea. $\mathrm{Pa}$ tients were encouraged and assisted to ambulate frequently during the 6-h infusion.

Control arm: standard local care alone.

Co-intervention: topical antibiotics and surgical debridement. Only 1 subject received concomitant hydroxycarbamide (in the control arm).

Outcomes Wound healing: partial healing (decrease in ulcer area by at least $25 \%$ of the baseline ulcer area) and complete healing (complete closure of the ulcer (to an area of $0 \mathrm{~cm}^{2}$ ).

Notes * If healing was objectively documented during the first 12-week treatment cycle, as determined by a decrease in measured ulcer area by at least $25 \%$ of the baseline area, arginine butyrate could be continued for two additional courses of 8-week cycles, although the responses to the extended treatment were not analysed as study endpoints. Control arm participants could cross-over to the treatment arm if their ulcer did not heal after 12 weeks of closely monitored and supervised standard local care. Their remaining ulcers were then assessed on the treatment arm for 12 weeks.

Sample size estimation a priori: no.

Country: USA.

Founders: the Food and Drug Administration, Office of Orphan Product Development (Grant FD-

R-000176) and the General Clinical Research Center at Boston University (Grant M01 RR00533).

\section{Risk of bias}

\begin{tabular}{lll}
\hline Bias & Authors' judgement & Support for judgement \\
\hline $\begin{array}{l}\text { Random sequence genera- } \\
\text { tion (selection bias) }\end{array}$ & Low risk & $\begin{array}{l}\text { Quote "table of random numbers prepared by a blinded statistician." (page } \\
517) .\end{array}$ \\
\hline $\begin{array}{l}\text { Allocation concealment } \\
\text { (selection bias) }\end{array}$ & Unclear risk & Insufficient information to permit judgement of 'low risk' or 'high risk'. \\
\hline
\end{tabular}


McMahon 2010 (Continued)

Blinding of participants Unclear risk Insufficient information to permit judgement of 'low risk' or 'high risk' and personnel (performance bias)

All outcomes

\begin{tabular}{|c|c|c|}
\hline $\begin{array}{l}\text { Blinding of outcome as- } \\
\text { sessment (detection bias) } \\
\text { All outcomes }\end{array}$ & Unclear risk & Insufficient information to permit judgement of 'low risk' or 'high risk' \\
\hline $\begin{array}{l}\text { Incomplete outcome data } \\
\text { (attrition bias) } \\
\text { All outcomes }\end{array}$ & Unclear risk & $\begin{array}{l}\text { Insufficient reporting of attrition/exclusions to permit judgement of 'low risk' } \\
\text { or 'high risk'. }\end{array}$ \\
\hline $\begin{array}{l}\text { Selective reporting (re- } \\
\text { porting bias) }\end{array}$ & Low risk & - \\
\hline Other bias & High risk & $\begin{array}{l}\text { Bias in the presentation of data (Appendix 2). } \\
\text { The inconsistency between 'randomisation unit: patient' and 'unit of analysis: } \\
\text { ulcers' could generate the design and confusion bias (Appendix 2). }\end{array}$ \\
\hline
\end{tabular}

\section{Serjeant 1977}

\section{Methods}

Design trial: parallel (two groups).

Study phase: III.

Baseline observation period: no (Dr Graham Serjeant, interviewed by one author of this review (JKM), on February 4, 2011).

Follow-up period: 6 months.

Randomisation unit: patients.

Unit of analysis: ulcers.

Intention-to-treat analysis: no (information was supplied by Dr Graham Serjeant, interviewed by one author of this review (JKM), on February 4, 2011).

Participants

\section{Enrolled: not described.}

Randomised: 40 (unclear). This number was confirmed by Dr Graham Serjeant, interviewed by one author of this review (JKM), on February 4, 2011.




Serjeant 1977 (Continued)

Allocated group: not mentioned.

Information about haemoglobin disorder type:

Homozygous sickle cell disease "Diagnosed by haemoglobin electrophoresis on cellulose acetate and agar gel, and quantification of $\mathrm{A}_{2}$ levels": 38 .

Sickle cell-haemoglobin $C$ disease: 1 .

Sickle cell-haemoglobin O (Arab) disease: 1.

Age (years): 17 to 67.

Gender (\% male): 52.5 (21/40).

Inclusion criteria: information was not supplied.

Exclusion criteria: information was not supplied.

\begin{tabular}{ll}
\hline Outcomes & Outcomes were not describe as primary or secondary. They were reported into 'results' section: \\
& Variation ulcer size; healed. \\
& $\begin{array}{l}\text { According with Dr Graham Serjeant, interviewed by one author of this review (JKM), 'ulcer area-change' } \\
\text { was the primary outcome (February 4, 2011). }\end{array}$ \\
\hline Notes & Centre and Country: Medical Research Council Laboratories, University of West India, Jamaica. \\
Sample size estimation a priori: no. \\
Support: Mead Johnson and Company. \\
Founder role: it supplied isoxsuprine hydrochloride and financial assistance.
\end{tabular}

\section{Risk of bias}

\begin{tabular}{|c|c|c|}
\hline Bias & Authors' judgement & Support for judgement \\
\hline $\begin{array}{l}\text { Random sequence genera- } \\
\text { tion (selection bias) }\end{array}$ & Unclear risk & $\begin{array}{l}\text { Quote " patients were allotted serial numbers in a code..." (page 164). } \\
\text { Insufficient information about the sequence generation process to permit } \\
\text { judgement of 'low risk' or 'high risk'. }\end{array}$ \\
\hline $\begin{array}{l}\text { Allocation concealment } \\
\text { (selection bias) }\end{array}$ & Unclear risk & Insufficient information to permit judgement of 'low risk' or 'high risk'. \\
\hline $\begin{array}{l}\text { Blinding of participants } \\
\text { and personnel (perfor- } \\
\text { mance bias) } \\
\text { All outcomes }\end{array}$ & Unclear risk & $\begin{array}{l}\text { Insufficient information to permit judgement of 'low risk' or 'high risk' } \\
\text { Comment: Dr Searjent referred this paper as blinded (Interviewed by one au- } \\
\text { thor of this review (JKM), on February 4, 2011). }\end{array}$ \\
\hline $\begin{array}{l}\text { Blinding of outcome as- } \\
\text { sessment (detection bias) } \\
\text { All outcomes }\end{array}$ & Unclear risk & Insufficient information to permit judgement of 'low risk' or 'high risk'. \\
\hline
\end{tabular}


Serjeant 1977 (Continued)

Incomplete outcome data High risk The number or reasons for dropouts and withdrawals were not described. (attrition bias)

All outcomes

Selective reporting (reporting bias)

Other bias Comments: this RCT loss 25\% (10/40) of the patients and 27\% (17/63) of the leg ulcers.
High risk

One or more clinically relevant and reasonably expected outcomes were not reported on; data on these outcomes were likely to have been recorded.
High risk

\author{
Quote "The code was kept by the producing company". \\ Comments. \\ 1. Characteristic baseline table: not shown. \\ 2. It is unclear data on randomisation unit reported by the authors. Dr Gra- \\ ham Serjeant pointed out unit of randomisation were the patients, and unit \\ of analysis were the ulcers (Interviewed by one author of this review (JKM), on \\ February 4, 2011). \\ 3. Ulcers developed during trail were included which were analysed. \\ 4. There is inconsistency regarding numbers of the total ulcers. \\ 5. Ascertaiment bias and bias in the presentation of data (Appendix 2). \\ 6. The inconsistency between 'Randomisation unit: patient' and 'Unit of \\ analysis: ulcers' could generate the design and confusion bias (Appendix 2).
}

Intention-to-treat analysis: declared. It was unclear, according with Dr Graham Serjeant, interviewed by one author of this review (JKM) on February 4, 2011.

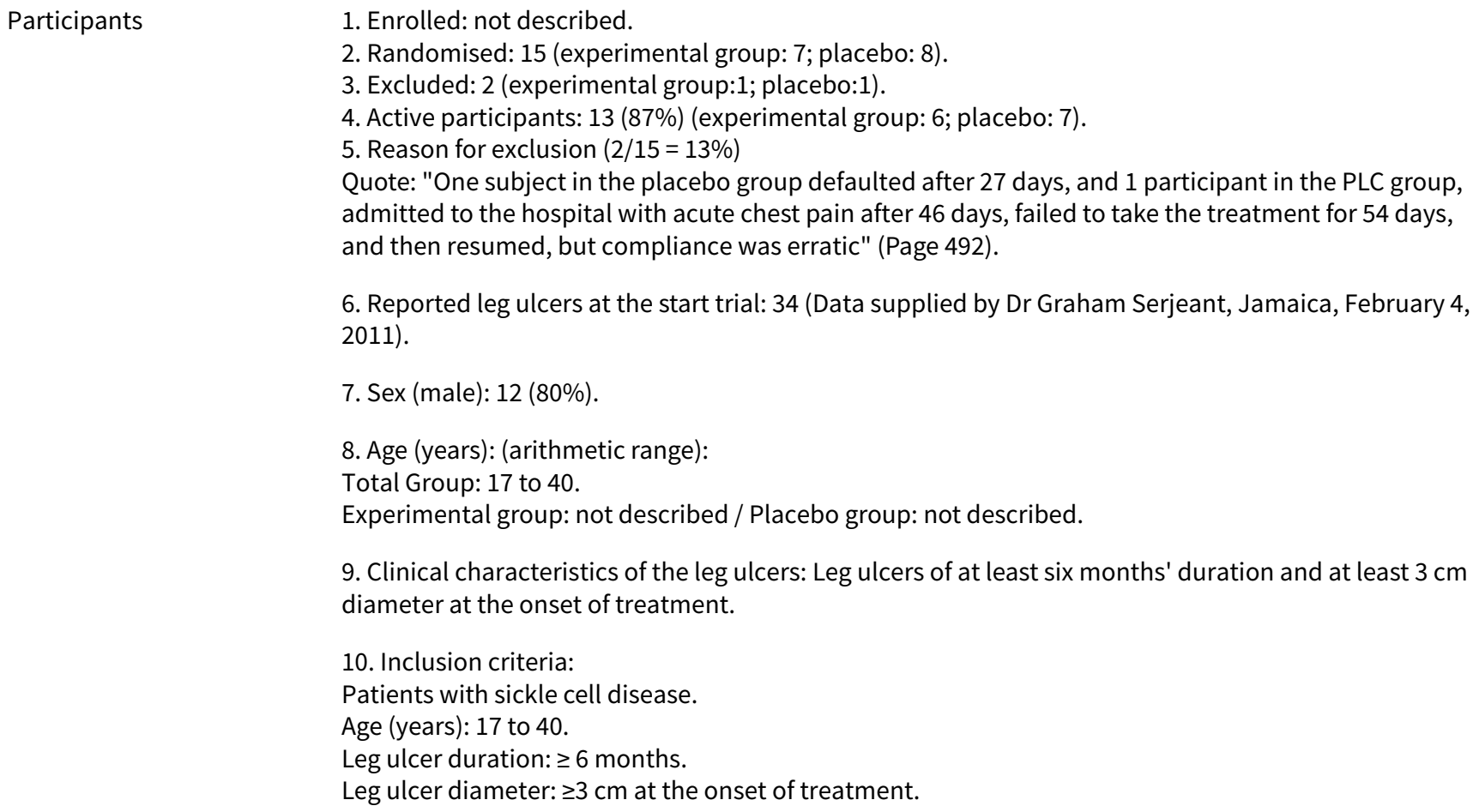


Serjeant 1997 (Continued)
11.- Exclusion criteria: not described.

Baseline treatment (12-weeks): all patients
1. Measurement of ulcers: at 2-week intervals.
2. Photographic images: at 4-week intervals.
3. Dressing with $0.01 \%$ potassium permanganate: twice daily.
4. Debridament of dirty ulcers with crushed unripe papaya.
5. Oral zinc sulphate: $200 \mathrm{mg}$ per oral, 3-times-daily, after meals.
Experimental group:
Propionyl-L-carnitine (PLC): $2 \mathrm{gr} /$ per oral/ twice-daily.
Control group:
Placebo: lactose and microcrystalline cellulose/per oral/twice-daily.
Co-interventions:
As for baseline period.

Outcomes

Healing rate.

Quote: "... was standardized to a 12-weeks period and expressed as (1) absolute change in area (change in ulcer area over treatment period divided by number of weeks on treatment ) $x 12$; and (2) percentage change in area (absolute change in area + area at start of treatment)" (page 491).

According with Dr Graham Serjeant, interviewed by one author of this review (JKM), 'ulcer area-change' was the primary outcome (February 4, 2011).

Notes

RCT start date: not described.

Centre and Country: Conducted at Medical Research Council Laboratories, University of West India, Jamaica.

A priori sample size estimation: 14 patients (7 patients by group).

- P-value: 0.05 .

- Healing rate: $15 \%$ over three months.

- Power: $80 \%$.

- Percentage healing rate: $74 \%$.

- Trail number: not described.

- Expected loss: not described.

Support: Sigma-Tau Pharmaceuticals, Gaittherborg, Md (Partial grant).

Founder role: not described.

\section{Risk of bias}

\section{Bias}

Authors' judgement Support for judgement

Random sequence genera- Unclear risk tion (selection bias)
Quote "...were randomly assigned to a treatment group, seven in the PLC group and eight in the placebo group" (pages 491-2).

Quote "randomisation within small blocks (2-4)" This information was supplied by Dr Serjeant on February 4, 2011.

Insufficient information about the sequence generation process to permit judgement of 'low risk' or 'high risk'.

Allocation concealment Unclear risk Insufficient information to permit judgement of 'low risk' or 'high risk'.


Serjeant 1997 (Continued)

Blinding of participants and personnel (performance bias)

All outcomes
Unclear risk Insufficient information to permit judgement of 'low risk' or 'high risk'

Comment: Dr Searjent referred this paper as blinded (Interviewed by one author of this review (JKM), on February 4, 2011).

Blinding of outcome as-
sessment (detection bias) $\quad$ Unclear risk Insufficient information to permit judgement of 'low risk' or 'high risk'

All outcomes

Incomplete outcome data Unclear risk (attrition bias)

Insufficient reporting of attrition/exclusions to permit judgement of 'low risk'

All outcomes or 'high risk'.

\begin{tabular}{|c|c|c|}
\hline $\begin{array}{l}\text { Selective reporting (re- } \\
\text { porting bias) }\end{array}$ & High risk & $\begin{array}{l}\text { if one or more clinically relevant and reasonably expected outcomes were not } \\
\text { reported on; data on these outcomes were likely to have been recorded. }\end{array}$ \\
\hline
\end{tabular}

\begin{tabular}{ll}
\hline Other bias & Design bias (Appendix 2). \\
& Comment: there is imbalance: ulcer size before treatment $\left(\mathrm{cm}^{2}\right)( \pm \mathrm{SD}):$ \\
& $\begin{array}{l}45.4(46.9)[4.9 \text { to } 146.28 \text { range] in placebo group vs } 19.7(4.7)[13.7 \text { to } 27.9] \text { in } \\
\text { experimental group. }\end{array}$ \\
&
\end{tabular}

\section{Wethers 1994}

\begin{tabular}{ll}
\hline Methods & Design trial: parallel (2 groups). \\
Multicenter study: yes \\
Study phase: no described. \\
Follow-up period: 10 weeks. \\
Baseline observation period: none declared. \\
Randomisation unit: patients. \\
Unit of analysis: patients. \\
Intention-to-treat analysis: yes. \\
\hline
\end{tabular}

Participants $\quad$ Randomised: 55 (RGD peptide matrix: 32) / placebo (23).

$\mathrm{Hb}$ genotype: HbSS (50), HbSP thalassaemia (2), HbSC (1), HbSC Harlem (1), HbSD (1).

Completed study: $48(87 \%)$. RDG peptide matrix $(27 / 32=84 \%)$, placebo $(21 / 23=91 \%)$

Loss: 7 (RGD peptide matrix: 5/32:16\% ) / placebo (2/23:9\%).

Imbalance between both groups: $7 \%$

Age: median( \pm SE) and range: RGD peptide matrix: 32.9(1.8) years, range 18 - 65 years; placebo: $36.6(2.3)$ years, range $26-65$ years.

Baseline ulcer duration (months) median( $\pm \mathrm{SE}$ ) and range: RGD peptide matrix: 52.0 months (12.6), range 1 - 312; placebo: 45.9 months (12.4), range 1 - 192).

Baseline ulcer area $\left(\mathrm{cm}^{2}\right)$ median $( \pm \mathrm{SE})$ and range: RGD peptide matrix: 14.8(3.3), range 0.4 -91.3; placebo: $11.0(2.4)$, range $0.9-36.7$.

Gender (male: female): RGD peptide matrix: 21:11; placebo: 12:11.

Inclusion criteria:

1. isolated full-thickness lower leg or ankle ulcers that did not involve bone or tendon and had persisted at least 1 month;

2. age: $\geq 18$ years old;

3. informed written consent.

Exclusion criteria: 
Wethers 1994 (Continued)

1. medical conditions that might retard healing (immune system, diseases, uncontrolled diabetes, bleeding disorders, neurological disorders, or cancer requiring chemotherapy or radiation treatment);

2. receiving medications that might adversely affect healing (systemic corticosteroids or antineoplastic agents);

3. history of chronic transfusion therapy within the 3 months preceding study commencement.

Interventions

RGD peptide matrix (Argidene gel: formerly Telio-Derm gel, Telios Pharmaceuticals, Inc, San Diego, CA). Applications and dressing changes: once per week by 10 weeks.

Placebo: saline solution.

Applications and dressing changes: once per week by 10 weeks.

Co-intervention: debridament and cleaning at each visit.

\begin{tabular}{ll}
\hline Outcomes & $\begin{array}{l}\text { Primary: changes in per cent ulcer closur } \\
\text { Secondary: none declared. }\end{array}$ \\
\hline Notes & $\begin{array}{l}\text { Country: conducted at USA. } \\
\text { Sample size estimation a priori: no. } \\
\text { Support: Telios Pharmaceuticals, Inc. } \\
\text { Founder role: none declared. }\end{array}$
\end{tabular}

\section{Risk of bias}

\section{Bias}

Random sequence genera- Unclear risk tion (selection bias)

\section{Authors' judgement Support for judgement}

Quote "sequentially assigned to treatment groups based on a unique randomization number list" (page 1776).

Comments: imbalance exists on 'baseline ulcer area $\left(\mathrm{cm}_{2}\right)$.

No Information reported about how "unique randomization number list" was generated.

\begin{tabular}{|c|c|c|}
\hline $\begin{array}{l}\text { Allocation concealment } \\
\text { (selection bias) }\end{array}$ & Unclear risk & Insufficient information to permit judgement of 'low risk' or 'high risk'. \\
\hline $\begin{array}{l}\text { Blinding of participants } \\
\text { and personnel (perfor- } \\
\text { mance bias) } \\
\text { All outcomes }\end{array}$ & Low risk & Patient and outcome assessor were blinded. \\
\hline $\begin{array}{l}\text { Blinding of outcome as- } \\
\text { sessment (detection bias) } \\
\text { All outcomes }\end{array}$ & Low risk & Patient and outcome assessor were blinded. \\
\hline $\begin{array}{l}\text { Incomplete outcome data } \\
\text { (attrition bias) } \\
\text { All outcomes }\end{array}$ & Low risk & Dropouts $<20 \%$ \\
\hline $\begin{array}{l}\text { Selective reporting (re- } \\
\text { porting bias) }\end{array}$ & Low risk & - \\
\hline Other bias & High risk & Design bias (Appendix 2). \\
\hline
\end{tabular}

bd: twice a day

SD: standard deviation

SE: standard error 
Characteristics of excluded studies [ordered by study ID]

\begin{tabular}{|c|c|}
\hline Study & Reason for exclusion \\
\hline Afifi 1979 & Author did not report data from the patients suffering sickle cell thalassaemia. \\
\hline Cacciola $1990 \mathrm{~b}$ & Not a randomised clinical trial. \\
\hline Lucena 2007 & Not a randomised clinical trial. \\
\hline Neves 2010 & Case report. \\
\hline Okany 2004 & Not a randomised clinical trial. \\
\hline Paggiaro 2010 & Case study. \\
\hline Sawyer 1979 & Case report including three types of ulcers. \\
\hline Serjeant 1970 & Not a randomised clinical trial. \\
\hline
\end{tabular}

\section{DATA AND ANALYSES}

\section{Comparison 1. L-carnitine versus placebo}

\begin{tabular}{lllll}
\hline Outcome or subgroup title & $\begin{array}{l}\text { No. of } \\
\text { studies }\end{array}$ & $\begin{array}{l}\text { No. of } \\
\text { partici- } \\
\text { pants }\end{array}$ & Statistical method & Effect size \\
\hline $\begin{array}{l}1 \text { Change in ulcer size (surface area or } \\
\text { volume) }\end{array}$ & 1 & Mean Difference (IV, Fixed, 95\% Cl) & Totals not selected \\
\hline 1.1 All randomised patients & 1 & Mean Difference (IV, Fixed, 95\% Cl) & $0.0[0.0,0.0]$ \\
\hline
\end{tabular}

Analysis 1.1. Comparison 1 L-carnitine versus placebo, Outcome 1 Change in ulcer size (surface area or volume).

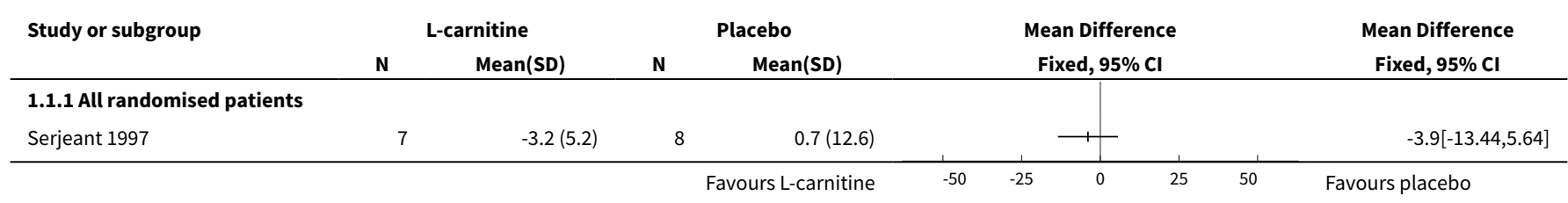


Comparison 2. RGD peptide matrix versus placebo

\begin{tabular}{lllll}
\hline Outcome or subgroup title & $\begin{array}{l}\text { No. of } \\
\text { studies }\end{array}$ & $\begin{array}{l}\text { No. of } \\
\text { partici- } \\
\text { pants }\end{array}$ & Statistical method & Effect size \\
\hline 1 Incidence of complete closure & 1 & Risk Ratio (M-H, Fixed, 95\% Cl) & Totals not selected \\
\hline 2 Change in size of ulcers healed & 1 & Mean Difference (IV, Fixed, 95\% Cl) & Totals not selected \\
\hline 3 Adverse events & 1 & Risk Ratio (M-H, Fixed, 95\% Cl) & Totals not selected \\
\hline 3.1 Total & 1 & Risk Ratio (M-H, Fixed, 95\% Cl) & $0.0[0.0,0.0]$ \\
\hline 3.2 Related study treatment & 1 & Risk Ratio (M-H, Fixed, 95\% Cl) & $0.0[0.0,0.0]$
\end{tabular}

Analysis 2.1. Comparison 2 RGD peptide matrix versus placebo, Outcome 1 Incidence of complete closure.

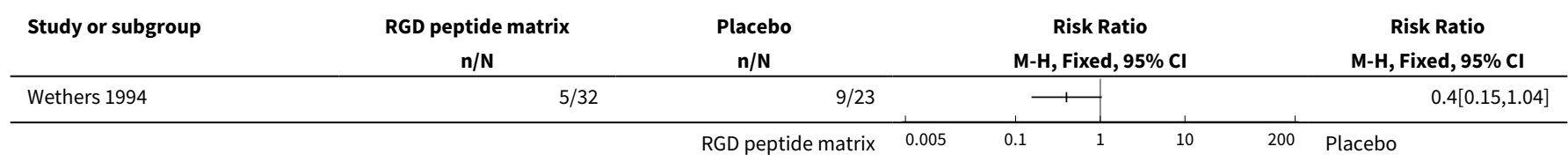

Analysis 2.2. Comparison 2 RGD peptide matrix versus placebo, Outcome 2 Change in size of ulcers healed.

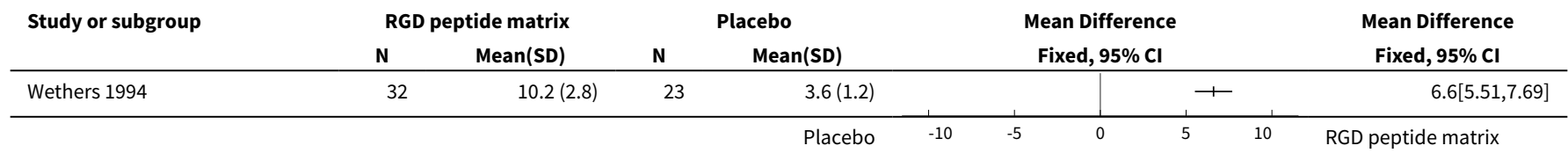

Analysis 2.3. Comparison 2 RGD peptide matrix versus placebo, Outcome 3 Adverse events.

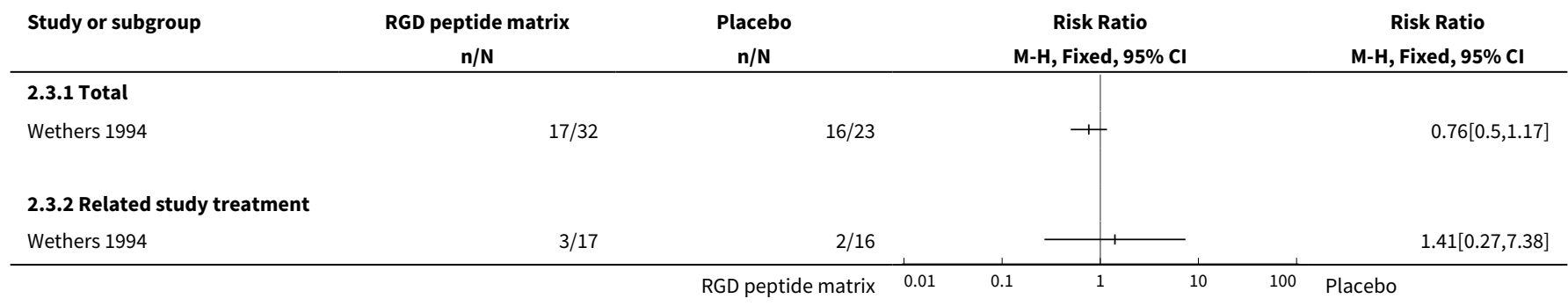

\section{APPEN DICES}

\section{Appendix 1. Glossary of medical terms.}




\begin{tabular}{lll}
\hline Terms & Definition & Source \\
\hline Hb SS & $\begin{array}{l}\text { An abnormal hemoglobin resulting from the substitution of valine for glutamic acid at po- } \\
\text { sition } 6 \text { of the beta chain of the globin moiety. The heterozygous state results in sickle cell } \\
\text { trait, the homozygous in sickle cell anemia. }\end{array}$ & $\begin{array}{l}\text { Nattional Library } \\
\text { of Medicine; Mesh } \\
\text { home page. }\end{array}$ \\
\hline Hb SC & $\begin{array}{l}\text { One of the sickle cell disorders characterized by the presence of both hemoglobin S and } \\
\text { hemoglobin C. It is similar to, but less severe than sickle cell anemia. }\end{array}$ & $\begin{array}{l}\text { Nattional Library } \\
\text { of Medicine; Mesh } \\
\text { home page. }\end{array}$
\end{tabular}

\begin{tabular}{ll}
\hline L-carnitine & $\begin{array}{l}\text { A derivative of the amino acid lysine, required for the transport of fatty acids into mito- } \\
\text { chondria for oxidation. }\end{array}$ \\
\hline Solcoseryl $l^{\oplus}$ & $\begin{array}{l}\text { Solcoseryl } \\
\text { and is a tissue metabolism activator, chemically and biologically standardized } \\
\text { of healthy young calf. Solcoseryl } \mathrm{l}^{\circledast} \text { contains a large amount of natural low molecular sub- } \\
\text { stances - glycolipides, nucleosides, nucleotides, amino acids, oligopeptides, irreplace- } \\
\text { able micro elements, electrolytes. }\end{array}$
\end{tabular}

Bender 2009

DuoDerm

Duoderm (Granuflex ${ }^{\circledast}$, Convatec, Uxbridge, UK, marketed as DuoDerm ${ }^{\circledast}$ in the USA) A hydrocolloid dressing containing colloids and elastomeric and adhesive components.

RGD peptide matrix
Arginine-glycine-aspartic acid (RGD). RGD peptide matrix is designed to act as a temporary, topical synthetic extracellular matrix that substitutes for the damaged natural matrix and provides support for cell ingrowth into the ulcer site. This synthetic matrix consists of an RGD-containing peptide complexed with sodium hyaluronate in a sterile, non preserved viscous gel.

Arginine-glycine-aspartic acid (RGD) peptide matrix (Argidene Gel ${ }^{\circledR}$, formerly Telio-Derm $\mathrm{Gel}^{\circledR}$, Telios Pharmaceuticals, San Diego, CA, USA) The peptide matrix contains the arginine-glycine-aspartic acid amino acid sequence, by which cells in vivo become attached to extracellular matrix macromolecules via surface integrin receptors. The matrix is a sterile non-preserved clear viscous gel, formulated in phosphate-buffered saline and dispensed from a single-use syringe container. The functional ingredient of RGD peptide matrix is a complex formed by the combination of a synthetic 18 amino acid peptide and sodium hyaluronate. It also contains added unconjugated sodium hyaluronate as a viscosity-increasing agent, and therefore does not require preparation from patient samples. http:// www.drugspro.org/
Wethers 1994

O'Meara 2000

$$
\text { ß-Adrenergic receptor stimulants drug. }
$$

Oral zinc sulphate

A salt of zinc used as a supplement for treating zinc deficiency

Bender 2009

\section{Arginine butyrate The butyric acid salt of the amino acid arginine.}

http://www.cancer.gov/drugdictionary

\begin{tabular}{lll}
\hline $\begin{array}{l}\text { Haemoglobinopa- } \\
\text { thy }\end{array}$ & $\begin{array}{l}\text { Any of a group of inherited diseases, such as thalassaemia and sickle-cell disease, in } \\
\text { which there is an abnormality in the production of haemoglobin. }\end{array}$ & Martin 2011 \\
\hline Priapism & $\begin{array}{l}\text { Persistent and usually painful erection of the penis that requires urgent decompression; } \\
\text { occasionally, however, it can be painless, in which case its treatment is less urgent. }\end{array}$ & Martin 2011 \\
\hline
\end{tabular}


(Continued)

Pulmonary hyper- Condition in which there is raised blood pressure within the blood vessels supplying the tension lungs (the pulmonary artery blood pressure is normally much lower than the pressure within the aorta and its branches).

Nitric oxide $\quad$ An important member of the group of gaseous mediators, which - together with amine
mediators (e.g. adrenaline, noradrenaline, histamine, acetylcholine) and lipid mediators
(e.g. prostaglandins) - produce many physiological responses

\begin{tabular}{llc}
\hline Endothelium & The single layer of cells that lines the heart, blood vessels, and lymphatic vessels. & Martin 2011 \\
\hline Antithrombin III & Coagulation inhibitory protein & Santen 2004
\end{tabular}

\section{Appendix 2. Bias definition}

\begin{tabular}{ll}
\hline Bias (Porta 2008) & Definition \\
\hline $\begin{array}{l}\text { Bias in the presentation } \\
\text { of data }\end{array}$ & $\begin{array}{l}\text { Error due to irregularities produced bi digit preference, incomplete data, } \\
\text { poor techniques of measurement, technically poor laboratory procedures, } \\
\text { or intentional attempts to mislead. }\end{array}$ \\
\hline Selection bias & Distortions that result from procedures used to select subjects and from factors that \\
& influence participation in the study. \\
\hline Reporting bias & Selective revealing or suppression of information. \\
\hline Design bias & The difference between a true value and that obtained as a result \\
& of faulty design of a study. \\
\hline
\end{tabular}

\section{Appendix 3. Outcome definitions as described by the RCTs' author}

\begin{tabular}{llll}
\hline Trials & Assessment of ulcer healing & $\begin{array}{l}\text { Change in ulcer size (surface area or vol- } \\
\text { ume) }\end{array}$ & $\begin{array}{l}\text { Complete } \\
\text { closure }\end{array}$ \\
\hline Baum 1987 & $\begin{array}{l}\text { "Ulcer was measured in two dimensions and pho- } \\
\text { tographs taken for determination of ulcer" as de- } \\
\text { scribed by Serjeant 1970. }\end{array}$ & - \\
\hline $\begin{array}{lll}\text { La Grenade } \\
1993\end{array}$ & $\begin{array}{l}\text { It was analysed from the measured long and short } \\
\text { dimensions of the ulcer, arbitrarily assuming and } \\
\text { elliptical shape. }\end{array}$ & $\begin{array}{l}\text { It was expressed as in real changes and per- } \\
\text { centage changes in area. }\end{array}$ & - \\
\hline McMahon & $\begin{array}{l}\text { "During the weekly clinical visits, the ulcer was } \\
\text { traced on acetate film and photographed. All } \\
\text { ulcer areas were then calculated by computer- } \\
\text { ized planimetry, using the IMAGEJ software (NIH, } \\
\text { Bethesda, MD, USA)". }\end{array}$ & NA & $\begin{array}{l}\text { Complete } \\
\text { closure of } \\
\text { the ulcer (to } \\
\text { an area of 0 } \\
\text { cm2). }\end{array}$ \\
\hline
\end{tabular}


(Continued)

Serjeant "The ulcer periphery was defined on the photo1977 graph, cut out, weighed, and the area of the ulcer calculated from the weight/area ratio of the photographic paper".
Default: "defined as less than 4 months satisfactorily attendance at the trial".

No change: "variation of less than $1 \mathrm{~cm}^{2}$ in ulcer area during the 6-month period".

Healed ulcers "expressed as a proportion of those ulcers likely to heal on the basis of small size $\left(8 \mathrm{~cm}^{2}\right)$.

Period: 12 weeks.

"(1) absolute change in area (change in ulcer area over treatment period divided by number of weeks on treatment) $\times 12$ and (2) percentage change in area (absolute change in area + area at start of treatment)".

Wethers "Changes in percent ulcer closure occurring be-

$1994 \quad$ tween study commencement and endpoint".

\section{Appendix 4. Unit of randomisation versus unit of analysis}

\begin{tabular}{lll}
\hline Study & Unit of randomisation & Unit of analysis \\
\hline Baum 1987 & participants & ulcer \\
\hline La Grenade 1993 & ulcer & ulcer \\
\hline McMahon 2010 & participants & ulcer \\
\hline Serjeant 1977 & participants & ulcer \\
\hline Serjeant 1997 & participants & participants \\
\hline Wethers 1994 & participants & participants
\end{tabular}

\section{Appendix 5. LILACS search strategy}

\section{Key words}

sickle cell disease

leg ulcer

((Pt ENSAYO CONTROLADO ALEATORIO OR Pt ENSAYO CLINICO CONTROLADO OR Mh ENSAYOS CONTROLADOS ALEATORIOS OR Mh DISTRIBUCIÓN ALEATORIA OR Mh METODO DOBLE CIEGO OR Mh METODO SIMPLECIEGO OR Pt ESTUDIO MULTICÉNTRICO) or ((tW enSaio or tw ensayo or tw trial) and (tw azar or tw acaso or tw placebo or tw control\$ or tw aleat\$ or tw random\$ or (tw duplo and tw cego) or (tw doble and tw ciego) or (tw double and tw blind)) and tw clinic\$)) AND NOT ((Ct ANIMALES OR Mh ANIMALES OR Ct CONEJOS OR Ct RATÓN OR 
MH Ratas OR MH Primates OR MH Perros OR MH Conejos OR MH Porcinos) AND NOT (Ct HUMANO AND Ct ANIMALES)) [Palabras] and sickle [Palabras del resumen] and ulcer [Palabras] (Strategy results:10)

\section{Appendix 6. African Index Medicus (AIM) search strategy}

\section{Key words}

sickle cell disease

leg ulcer

wound

Search result: 0 references.

\section{Appendix 7. ISI Web of Knowledge}

\section{Key words}

sickle

leg ulcer

Search result: 47 references.

\section{WHAT'S NEW}

\begin{tabular}{lll}
\hline Date & Event & Description \\
\hline 21 October 2014 & New search has been performed & $\begin{array}{l}\text { The searches did not identify any potentially relevant trials for } \\
\text { inclusion in the review. }\end{array}$ \\
\hline 21 October 2014 & $\begin{array}{l}\text { New citation required but conclusions } \\
\text { have not changed }\end{array}$ & Minor changes were made throughout the review. \\
\hline
\end{tabular}

\section{H I S T O R Y}

Protocol first published: Issue 3, 2010

Review first published: Issue 11, 2012

\begin{tabular}{lll}
\hline Date & Event & Description \\
\hline 24 January 2013 & Amended & Contact details updated. \\
\hline
\end{tabular}

\section{CONTRIBUTIONS OF AUTHORS}

Arturo Martí-Carvajal conceived and drafted the review with comments from Jennifer Knight-Madden and María José Martínez-Zapata. Arturo Martí-Carvajal acts as guarantor for the review. 


\section{DECLARATIONS OF INTEREST}

In 2004 Arturo Martí-Carvajal was employed by Eli Lilly to run a four-hour workshop on 'How to critically appraise clinical trials on osteoporosis and how to teach this'. This activity was not related to his work with The Cochrane Collaboration or any Cochrane Review.

In 2007 Arturo Martí-Carvajal was employed by Merck to run a four-hour workshop 'How to critically appraise clinical trials and how to teach this'. This activity was not related to his work with The Cochrane Collaboration or any Cochrane Review.

Jennifer Knight-Madden and María José Martínez-Zapata: none known.

\section{SOURCES OF SUPPORT}

\section{Internal sources}

- No sources of support supplied

\section{External sources}

- Iberoamerican Cochrane Center, Spain.

Academic

- Cystic Fibrosis and Genetic Disorders Group, UK.

Academic

\section{IN DEX TERMS}

\section{Medical Subject Headings (MeSH)}

*Bandages; Actihaemyl [therapeutic use]; Anemia, Sickle Cell [ ${ }^{*}$ complications]; Anti-Bacterial Agents [therapeutic use]; Arginine [analogs \& derivatives] [therapeutic use]; Butyrates [therapeutic use]; Carnitine [therapeutic use]; Isoxsuprine [therapeutic use]; Leg Ulcer [ ${ }^{\star}$ drug therapy] [etiology]; Oligopeptides [therapeutic use]; Randomized Controlled Trials as Topic

\section{MeSH check words}

Humans 